\title{
Mechanisms for Generation and Development of the Ningaloo Niño $\mathscr{O}$
}

\author{
LEI ZHANG, WEIQING HAN, AND YUANLONG LI \\ Department of Atmospheric and Oceanic Sciences, University of Colorado Boulder, Boulder, Colorado \\ TOSHIAKI SHINODA \\ Department of Physical and Environmental Sciences, Texas A\&M University, Corpus Christi, Texas
}

(Manuscript received 23 March 2018, in final form 31 August 2018)

\begin{abstract}
Generation and development mechanisms of the Ningaloo Niño are investigated using ocean and atmospheric general circulation model experiments. Consistent with previous studies, northerly wind anomalies off the West Australian coast are critical in generating warm sea surface temperature (SST) anomalies of the Ningaloo Niño, which induce SST warming through reduced turbulent heat loss toward the atmosphere (by decreasing surface wind speed), enhanced Leeuwin Current heat transport, and weakened coastal upwelling. Our results further reveal that northerly wind anomalies suppress the cold dry air transport from the Southern Ocean to the Ningaloo Niño region, which also contributes to the reduced turbulent heat loss. A positive cloud-radiation feedback is also found to play a role. Low stratiform cloud is reduced by the underlying warm SSTAs and the weakened air subsidence, which further enhances the SST warming by increasing downward solar radiation. The enhanced Indonesian Throughflow also contributes to the Ningaloo Niño, but only when La Niña co-occurs. Further analysis show that northerly wind anomalies along the West Australian coast can be generated by both remote forcing from the Pacific Ocean (i.e., La Niña) and internal processes of the Indian Ocean, such as the positive Indian Ocean dipole (IOD). Approximately $40 \%$ of the Ningaloo Niño events during 1950-2010 co-occurred with La Niña, and 30\% co-occurred with positive IOD. There are also $\sim 30 \%$ of the events independent of La Niña and positive IOD, suggesting the importance of other processes in triggering the Ningaloo Niño.
\end{abstract}

\section{Introduction}

In austral summer of 2010/11, unprecedented warm sea surface temperature (SST) anomalies (SSTAs) occurred off the Western Australian coast, with a peak warming of $5^{\circ} \mathrm{C}$ (Feng et al. 2013). Such a pronounced oceanic warming resulted in massive coral bleaching and fish kills (Stenseth 2002; Depczynski et al. 2013; Zinke et al. 2014; Zhang et al. 2017), posing a severe threat to the local marine ecosystem. The warm SSTA is also associated with more precipitation over Western Australia and affects the local climate (Kataoka et al. 2014; Tozuka et al. 2014). This extreme warming event is a manifestation of the strong interannual SST variability

Supplemental information related to this paper is available at the Journals Online website: https://doi.org/10.1175/JCLID-18-0175.s1.

Corresponding author: Lei Zhang, lezh8230@colorado.edu over the southeast Indian Ocean, which is dubbed "Ningaloo Niño" (Feng et al. 2013), analogous to the El Niño of the equatorial Pacific.

The SST warming off the west coast of Australia during the Ningaloo Niño is normally accompanied by evident low-level cyclonic wind anomalies over the southeast Indian Ocean, along with a strengthened Leeuwin Current and weakened coastal upwelling (Kataoka et al. 2014; Benthuysen et al. 2014; Marshall et al. 2015). Physical causes of these anomalies may involve local ocean-atmosphere interaction (Kataoka et al. 2014). The warm SSTA over the Ningaloo Niño region drives low-level cyclonic wind anomalies to its west; the associated coastal northerly wind anomalies reduce the mean wind speed, enhance the Leeuwin Current, and weaken the coastal upwelling, all of which further promote the local SST warming (Feng et al. 2013; Kataoka et al. 2014; Marshall et al. 2015). This positive feedback loop may amplify both wind and SST anomalies initially triggered by other factors. 
In addition to the local air-sea interaction, variations of wind and ocean current associated with the Ningaloo Niño can also be caused by remote forcing from the tropical Pacific associated with La Niña through both oceanic connection and the atmospheric bridge (Feng et al. 2013; Kataoka et al. 2014; Tozuka et al. 2014; Feng et al. 2015; Benthuysen et al. 2014). The enhanced Indonesian Throughflow (ITF) during La Niña, along with downwelling coastal Kelvin waves propagating poleward along the west coast of Australia, enhances the Leeuwin Current and weakens the coastal upwelling, contributing to the SST warming (Clarke and Liu 1994; Meyers 1996; Feng et al. 2013; Kataoka et al. 2014; Zinke et al. 2014; $\mathrm{Li}$ et al. 2017). The enhanced atmospheric convection over the Maritime Continent during La Niña also induces low-level cyclonic winds over the south Indian Ocean (Gill 1980), which also causes SST warming over the Ningaloo Niño region (Lau and Nath 2000; Kataoka et al. 2014; Tozuka et al. 2014). Kido et al. (2016) examined the performance of climate models in simulating the Ningaloo Niño and found large intermodel differences. They also underscored the importance of Pacific remote forcing in the modeled Ningaloo Niño characteristics. Consistent with the prominent impact of La Niña on the Ningaloo Niño, Hendon and Wang (2010) showed that the Leeuwin Current variation, which is an important driver of the Ningaloo Niño and is closely tied to the ENSO forcing, can be well predicted at a 9-month lead. Doi et al. (2013) also shows that the Ningaloo Niño can be reasonably predicted two seasons ahead, thanks to the high prediction skill of La Niña.

Apparently, existing studies have identified several physical processes possibly affecting the generation and development of the Ningaloo Niño, yet their relative importance has not been accurately quantified, hindering a thorough understanding of this important climate phenomenon. In addition, although La Niña events are in favor of generating Ningaloo Niños, many Ningaloo Niño events occurred independently from La Niña (Kataoka et al. 2014; Marshall et al. 2015), suggesting a potentially important role played by the Indian Ocean internal processes. Consequently, understanding the relative importance of local and remote forcing in causing the Ningaloo Niño is both scientifically important and societally relevant.

In this study, we investigate the generation and development mechanisms of the Ningaloo Niño by performing a hierarchy of ocean general circulation model (OGCM) experiments, which are designed to isolate effects of different processes on the Ningaloo Niño SSTA. Atmospheric GCM (AGCM) experiments are also performed to understand the effect of the Indian
Ocean dipole (IOD; Saji et al. 1999; Webster et al. 1999) in triggering the Ningaloo Niño. This paper is organized as follows. Section 2 provides detailed descriptions of data, the OGCM and AGCM used in this study, and the experiment design. Section 3 analyzes the contributions of various physical processes to the SSTAs of the Ningaloo Niño. Section 4 investigates the relative roles of local and remote forcing in causing the Ningaloo Niño. Finally, section 5 provides a summary and discussion.

\section{Data and methodology}

\section{a. Observations}

In this study, we analyze the SST data from the Hadley Centre Sea Ice and Sea Surface Temperature dataset (HadISST; Rayner et al. 2003) and the National Oceanic and Atmospheric Administration (NOAA) Extended Reconstructed SST, version 4 (ERSSTv4; Huang et al. 2015). We also analyze daily and monthly fields of the European Centre for Medium-Range Weather Forecasts (ECMWF) Twentieth Century Reanalysis (ERA20C; Poli et al. 2016), including precipitation, surface air temperature, specific humidity, net shortwave and longwave radiation, 10-m wind, and cloud cover. We choose the analysis period of 1950-2010, even though the ERA-20C data are available over the twentieth century until 2010, because of the larger uncertainties of the datasets before the 1950s that result from sparse observations (Deser et al. 2010). Satellite observations of SST from the NOAA Optimum Interpolation Sea Surface Temperature (OISST; Reynolds et al. 2002), and ocean currents from Simple Ocean Data Assimilation, version 2.2.4 (SODA2.2.4; Carton and Giese 2008), are also analyzed.

\section{b. OGCM experiments}

The OGCM utilized in this study is the Hybrid Coordinate Ocean Model, version 2.2.18 (HYCOM; Bleck 2002). HYCOM has been widely used to address ocean dynamic and thermodynamic processes in the IndoPacific Ocean (Han 2005; Han et al. 2007; Duncan and Han 2009; Trenary and Han 2012; Wang et al. 2012). In HYCOM, the Coupled Ocean-Atmosphere Response Experiment, version 3.0 (COARE 3.0), algorithm (Fairall et al. 2003; Kara et al. 2005) is used to calculate the surface latent heat $(\mathrm{LH})$ and sensible heat ( $\mathrm{SH})$ fluxes: $\mathrm{LH}=L C_{L} \rho_{a} V_{a}\left(q_{a}-q_{s}\right)$ and $\mathrm{SH}=C_{P} C_{S} \rho_{a} V_{a}\left(T_{a}-T_{s}\right)$, where $\rho_{a}$ denotes the surface air density, $V_{a}$ is the surface wind speed, $q_{s}$ and $q_{a}$ represent the saturation specific humidity of sea surface and specific humidity of surface air, and $T_{s}$ and $T_{a}$ are SST and surface air temperature, respectively. The variable 
TABLE 1. Atmospheric forcing fields specified in the OGCM sensitivity experiments. The Pacific has full daily forcing, while the forcing fields over the Indian Ocean vary in Exp1-Exp5. Modification of surface forcing fields for Exp2, Exp3, Exp4, and Exp5 are all relative to Exp1. Various physical processes assessed in these experiments are summarized in the last column. Wstress is wind stress, Wspeed is wind speed, and SWR is shortwave radiation.

\begin{tabular}{llcl}
\hline & \multicolumn{1}{c}{ Indian Ocean forcing } & Pacific forcing & Impact on Indian Ocean SST \\
\hline CTRL & Full forcing & Full forcing & All processes included \\
Exp1 & Climatological seasonal cycle & Full forcing & Indonesian Throughflow (ITF) \\
Exp2 & Full surface Wstress & Full forcing & Exp2 - Exp1, Wstress-driven dynamics \\
Exp3 & Full wind (Wstress + Wspeed) & Full forcing & Exp3 - Exp2, Wspeed related turbulent \\
& & & heat flux \\
Exp4 & ENSO Wstress & Full forcing & Exp4 - Exp1, ENSO Wstress; Exp2 - \\
& & Exp4, Local IO Wstress \\
Exp5 & ENSO Wspeed + SWR & Full forcing & Exp5 - Exp1, ENSO Wspeed + SWR \\
\hline
\end{tabular}

$L$ is the latent heat of evaporation, and $C_{P}$ is the specific heat of air. Here $C_{L}$ and $C_{s}$ are the heat exchange coefficients of $\mathrm{LH}$ and $\mathrm{SH}$, respectively.

In this study, we configure the HYCOM to the IndoPacific basin $\left(55^{\circ} \mathrm{S}-55^{\circ} \mathrm{N}, 19^{\circ} \mathrm{E}-68^{\circ} \mathrm{W}\right)$, with a horizontal resolution of $1 / 3^{\circ} \times 1 / 3^{\circ}$ over $25^{\circ} \mathrm{S}-25^{\circ} \mathrm{N}, 70^{\circ}-170^{\circ} \mathrm{E}$, which gradually increased to $1^{\circ} \times 1^{\circ}$ outside this region. The model has 35 hybrid vertical layers. The HYCOM was spun up for 30 years. Restarting from the spunup solution of year 30, HYCOM was integrated forward in time from 1950 to 2010, with daily forcing fields from the ERA-20C. This experiment is referred to as the control run (CTRL). The Indian Ocean mean state during austral summer, the peak season of the Ningaloo Niño, is reproduced reasonably well in CTRL compared with observational datasets, including the SST distribution and the strong coastally trapped meridional ocean current (i.e., the Leeuwin Current; see Fig. S1 in the online supplemental material). Note that the simulation ends in December 2010, after which the ERA-20C data are not available. As a result, the unprecedented Ningaloo Niño event in austral summer of 2010/11 is not fully captured by our analysis, but analysis of the observational SST dataset that includes the 2010/11 event shows similar results to those shown in this study.

To assess effects of different forcing and processes, five sensitivity experiments were conducted (Table 1), in which modified forcing fields were used for the Indian Ocean, while the same daily forcing as in CTRL was used for the Pacific Ocean. (Definition of the Indian Ocean and the Pacific domains is shown in Fig. S2.) In Exp1, the Indian Ocean was forced by climatological seasonal cycles of all forcing fields, and thus the interannual SST variability over the Indian Ocean in this experiment is solely caused by ITF variations, which are primarily associated with El Niño-Southern Oscillation (ENSO).

In Exp2, full daily surface wind stress forcing was used to force the Indian Ocean; otherwise, it is the same as
Exp1. The difference, Exp2 - Exp1, measures the effect of wind stress-driven oceanic processes (e.g., advection, upwelling, and entrainment) in the Indian Ocean on the SST variability. Full daily surface wind forcing (wind speed and wind stress) was used to force the Indian Ocean in Exp3; therefore, the difference, Exp3 - Exp2, assesses the effect of surface turbulent heat flux anomalies caused by wind speed variation.

The other two experiments, Exp4 and Exp5, isolate ENSO's impacts on the Indian Ocean via the atmospheric bridge. In Exp4, ENSO-related surface wind stress anomalies over the Indian Ocean (see section 2d) are added to the climatological seasonal cycle; otherwise, it is the same as Exp1. Exp4 - Exp1 thus estimates the ENSO's impact through the wind stress-driven ocean circulation. Exp5 is the same as Exp4, except that ENSOrelated surface shortwave radiation and surface wind speed anomalies (causing changes in surface turbulent heat flux) are added to their seasonal cycles over the Indian Ocean. The solution difference, Exp5 - Exp1, isolates the surface turbulent flux and shortwave radiation effects of the ENSO's atmospheric bridge. Note that ocean internal variability, such as instabilities of the local circulation and mesoscale eddies (e.g., Feng et al. 2005; Jia et al. 2011), may also generate interannual SSTA and thus affect the Ningaloo Niño. This effect, however, is shown to be negligible (see section $3 \mathrm{~b}$ below).

\section{c. AGCM experiments}

AGCM experiments were conducted to examine the role of the positive IOD in generating the Ningaloo Niño (see section 4), using the Max Planck Institute (MPI) ECHAM 4.6 (Roeckner et al. 1996). The model resolution is T42, with 19 vertical levels. ECHAM4.6 has been widely used to study atmospheric responses to large-scale SSTA forcing in tropics (Fu et al. 2003; Zhang and Li 2017; Zhang and Karnauskas 2017). In addition to the control run, which is forced with climatological monthly SST, a sensitivity experiment was 
(a) HadISST EOF1 (57.0\%)

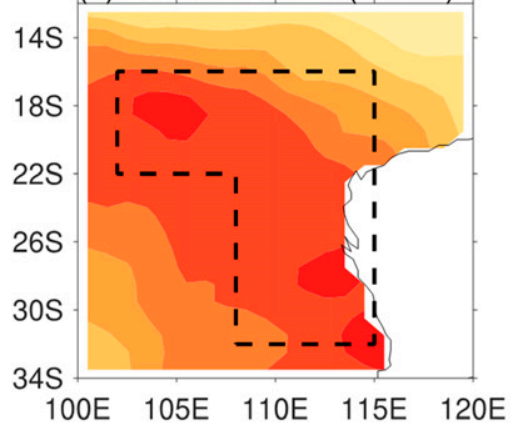

(b) ERSSTV4 EOF1 (59.0\%)

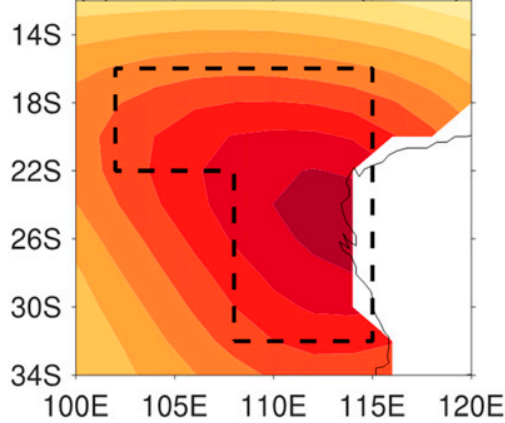

(c) CTRL EOF1 (37.0\%)

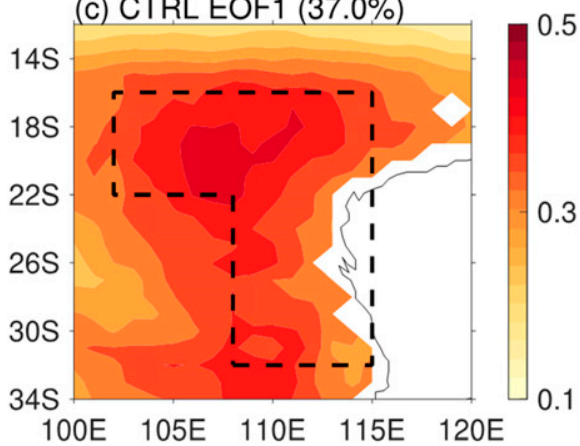

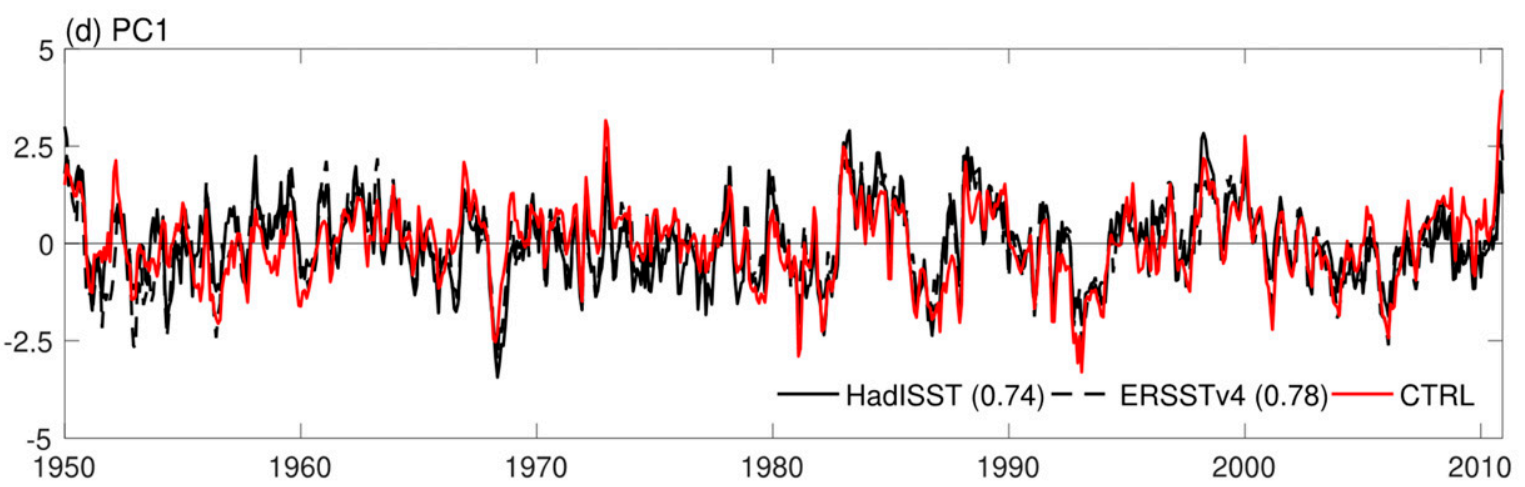

(e) Ningaloo Nino Index

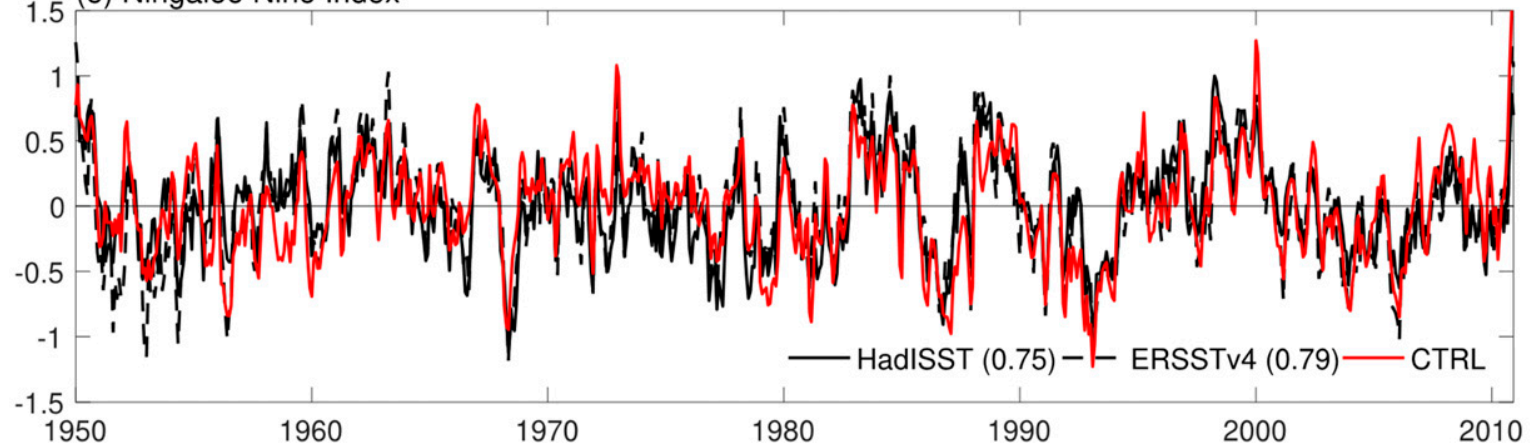

FIG. 1. The leading empirical orthogonal function (EOF1) mode of the detrended monthly SSTA (K) (with monthly climatology removed) for (a) HadISST, (b) ERSSTv4, and (c) HYCOM CTRL. Shown in the parentheses is the variance explained by the EOF1 mode. The EOF2 mode in CTRL explains $\sim 14 \%$ of total variance, and therefore the EOF1 and EOF2 modes are well separated. (d) The PC corresponding to the EOF1 mode. The solid black curve represents the result for HadISST, dashed black represents the result for ERSSTv4, and solid red represents the result for HYCOM CTRL. The number in the parentheses is the correlation coefficient with the PC1 of HYCOM CTRL. (e) As in (d), but for the NNI, defined as SSTA averaged over the boxed region in (a) $-(\mathrm{c})\left(22^{\circ}-16^{\circ} \mathrm{S}, 102^{\circ}-108^{\circ} \mathrm{E}\right.$ and $\left.32^{\circ}-16^{\circ} \mathrm{S}, 108^{\circ}-115^{\circ} \mathrm{E}\right)$.

conducted, with monthly SSTAs associated with positive IOD events added to the tropical Indian Ocean (see section 4). The SSTA fields are obtained through a composite analysis of HadISST. SSTAs are prescribed over a 2-yr period, from January of the positive IOD developing year to December of the following year. For both experiments, the model was integrated for 40 years, and the first 6 years were discarded given that it takes a few years to reach the model equilibrium state. Both experiments were repeated four times, with slightly different initial conditions. Hence, a 68-member ensemble, $(40-6) / 2 \times 4$, is available for analysis.

\section{d. Methods}

To obtain the spatial-temporal characteristics of the Ningaloo Niño, we conduct empirical orthogonal function (EOF) analysis of detrended, monthly SSTA over the southeast Indian Ocean (Fig. 1), following Kataoka et al. (2014) and Marshall et al. (2015). The first dominant mode represents the Ningaloo Niño, with its 
corresponding principal component (PC) highly correlated with the Ningaloo Niño index (NNI). See section 3 for the definition of NNI. In this study, a Ningaloo Niño event is defined as the year with the DecemberFebruary (DJF) NNI exceeding one standard deviation of monthly NNI of the period 1950-2010. One exception is the year 2010, for which the December NNI is used because ERA-20C data and HYCOM simulations end there. Similarly, the La Niña year is defined as when the DJF Niño-3.4 index falls below one negative standard deviation. The positive IOD year is defined as when the September-November (SON) dipole model index (DMI) exceeds one standard deviation. Unless otherwise stated, all variables in this study have been detrended.

The Bayesian dynamic linear model (DLM; Petris et al. 2009) is used to obtain surface wind stress, surface shortwave radiation, and surface wind speed anomalies over the Indian Ocean associated with ENSO, which are then used to force Exp4 and Exp5. The advantage of the Bayesian DLM over the conventional linear regression model lies in the fact that it is capable of capturing the nonstationary relation between ENSO and its impact over the Indian Ocean. Interested readers are referred to Han et al. (2017) for more detailed discussions.

\section{Physical processes associated with the Ningaloo Niño}

\section{a. Observed/simulated Ningaloo Niño}

The Ningaloo Niño is described by the leading EOF mode of the southeast Indian Ocean SSTA, manifest as pronounced SST warming off the West Australian coast, extending northwestward into the tropical Indian Ocean (Figs. 1a-c). The corresponding PC exhibits evident variability at interannual time scales (Fig. 1d). The HYCOM CTRL, which is forced by full forcing fields in the Indo-Pacific region, is capable of simulating the spatial-temporal characteristics of the Ningaloo Niño reasonably well (Fig. 1). However, there are noticeable discrepancies between the modeled and the observed SSTA. In particular, the SST warming in CTRL is significantly underestimated near the west coast of Australia compared to ERSSTv4, but is somewhat similar to HadISST. Such a discrepancy could be associated with the nonresolved bathymetry in the coastal area and the underestimated coastal dynamics [e.g., topographic trapping of Rossby wave energy and thus the Leeuwin Current and SSTA to the coastal region; Furue et al. (2013)]. Using data after 1982 (when satellite observations are available) yields similar results (Fig. S3). Consequently, the model/data and the cross-data differences are not due to the low data quality during the early period. Despite this discrepancy, the PC1 of the CTRL is well correlated with that of HadISST $(r=0.74)$ and ERSSTv4 $(r=0.78)$, compared to the correlation of $r=0.87$ between HadISST and ERSSTv4. All of these correlations exceed $99 \%$ significance.

Here, we define a Ningaloo Niño index (Fig. 1e) based on the EOF1 pattern, which is the time series of SSTA averaged over the domain from the west coast of Australia extending northwestward to the tropical Indian Ocean (boxed region of Figs. 1a-c). Note that this domain is similar to those in Kataoka et al. (2014) and Marshall et al. (2015), but is slightly modified to better capture the northwest-oriented SST warming pattern. The correlations between the NNI and PC1 are remarkably high, with $r=0.96$ on average, and the observed NNI is also highly correlated with the CTRLsimulated NNI (Fig. 1e). Both the PC1 and the NNI capture the unprecedented warming surge in December 2010. Seasonal variation of the monthly standard deviation of the NNI reveals that the Ningaloo Niño peaks in austral summer (i.e., DJF) in both model and observations (Fig. 2), consistent with previous findings (Feng et al. 2013; Kataoka et al. 2014; Marshall et al. 2015). Hence, we focus on DJF in this study. The seasonality of the NNI is less evident in HadISST compared to ERSSTv4 and HYCOM.

\section{b. Physical processes}

To isolate various physical processes that may cause the SSTA of the Ningaloo Niño, solutions of HYCOM experiments are analyzed (Fig. 3). In Exp1, forcing fields over the Indian Ocean only contain the climatological seasonal cycle, and therefore, the interannual variability of the Indian Ocean SSTA is mainly caused by ENSO via the ITF. Note that oceanic internal instabilities can also induce interannual SSTA. This effect, however, is negligible, since the standard deviation of interannual SSTA averaged in the NNI region from the last 20 years of the spinup experiment, which is forced by the monthly climatologic cycle, is only $\sim 0.03 \mathrm{~K}$. During La Niña, sea surface height (SSH) is elevated in the western tropical Pacific (Fig. 4a), which is associated with increased ITF volume transport. After entering the Indian Ocean, the high SSH signals propagate along the west coast of Australia as coastal-trapped waves (Fig. 4b), enhancing the Leeuwin Current and causing anomalous coastal downwelling, contributing to positive SSTA of the Ningaloo Niño (Fig. 3b). As we shall see in section 4 below, the ITF effect on the Ningaloo Niño is only evident during La Niña years, which are only approximately $40 \%$ of the total Ningaloo Niño events. Opposite processes occur for El Niño and Ningaloo Niña events. Here, the 
Ningaloo Niña refers to SST cooling events in the southeast Indian Ocean.

Effects of wind stress-driven ocean dynamics (e.g., upwelling, advection and entrainment) and wind speedcontrolled turbulent heat fluxes in the Indian Ocean are assessed by Exp2 - Exp1 and Exp3 - Exp2, respectively (see section $2 \mathrm{~b}$ and Table 1 ). During the Ningaloo Niño, strong surface northerly wind anomalies are located off the west coast of Australia, which are associated with low-level cyclonic wind anomalies over the south Indian Ocean (Fig. 4a). Wind stress anomalies strengthen the Leeuwin Current and induce anomalous coastal downwelling, causing SST warming (Fig. $3 c)$. This effect is particularly evident over the coastal region, although it also contributes to the offshore SST warming. Northerly wind anomalies over the Ningaloo Niño region also reduce the local mean wind speed and thereby contribute substantially to the local SST warming via decreasing the surface turbulent heat flux (Fig. 3d). The overall local wind forcing effect on the SST warming is larger than the ITF effect, given that the latter only contributes during La Niña events (see section 4).

Two distinct processes can cause surface wind anomalies over the southeast Indian Ocean. One is the atmospheric bridge imprints of the tropical Pacific (primarily ENSO). The other is related to the Indian Ocean internal ocean-atmosphere interaction processes (Kataoka et al. 2014). Here, we separate the wind anomalies and their impacts into ENSO-related and ENSO-independent components (Figs. 3e, 3f, 4c, and 4d). La Niña indeed causes surface cyclonic wind anomalies over the south Indian Ocean during the Ningaloo Niño, but its associated coastal northerly wind stress anomalies are weak, corresponding to weak positive SST and SSH anomalies (Figs. 3e and 4c). In contrast, strong northerly wind anomalies off the west and northwest coast of Australia are associated with the Indian Ocean internal processes, which cause substantial local SST warming that explains approximately $80 \%$ of the total wind stress effect on SST, compared to the $\sim 20 \%$ warming induced by ENSO via the atmospheric bridge (Figs. 3c, 3f, and 4d). As we shall see in section 4, positive IOD events can induce northerly wind anomalies over the Ningaloo Niño region even during El Niño years. As a result, the coherent relation between coastal northerly wind anomalies and La Niña events may not be captured by the static linear regression analysis shown in Fig. 4c. Composite analysis indeed suggests that La Niña events play important roles in causing some Ningaloo Niño events (section 4).

Relative roles of different physical processes are further quantified by examining the NNI time series from
Monthly standard deviation of NNI

(a) HadISST

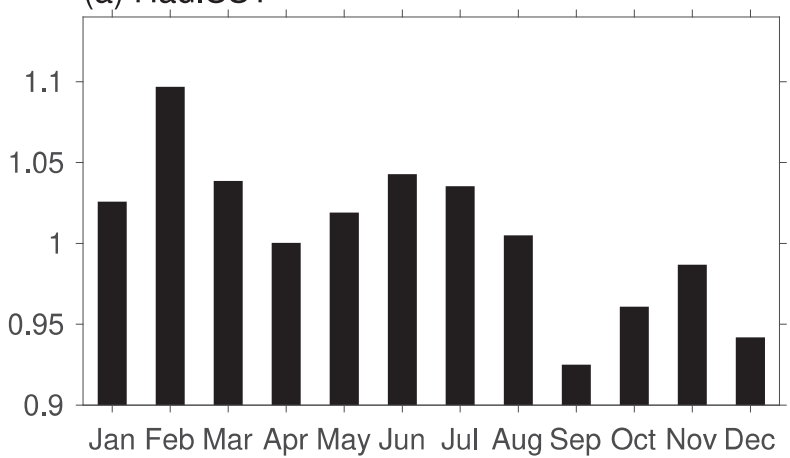

(b) ERSSTv4

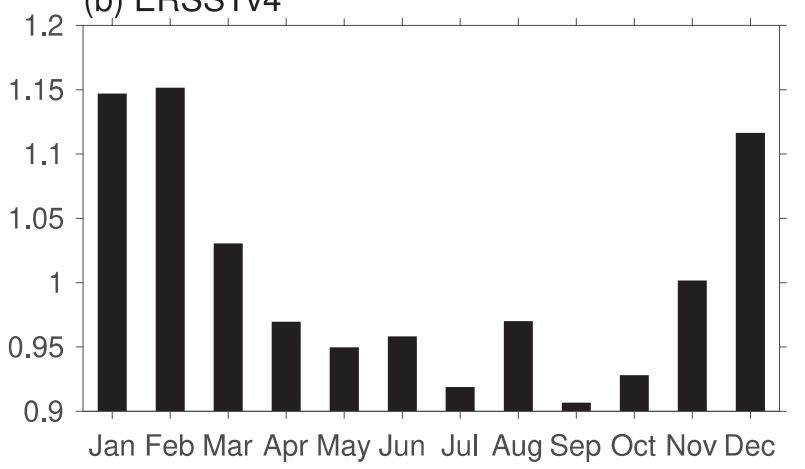

(c) CTRL

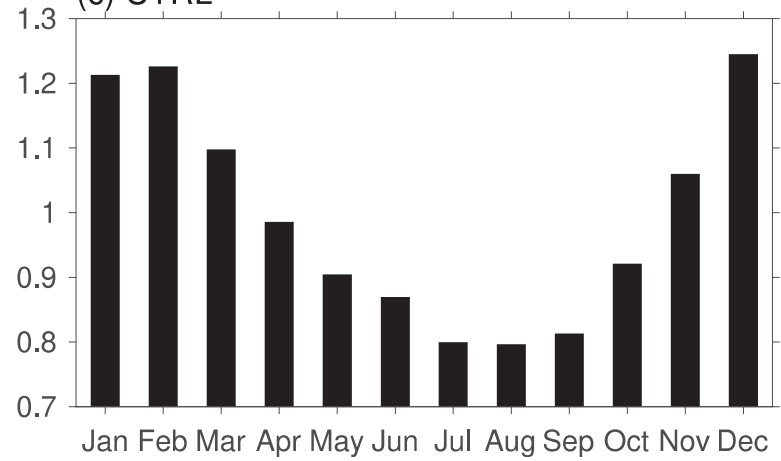

FIG. 2. Monthly standard deviation of the normalized NNI (K) in (a) HadISST, (b) ERSSTv4, and (c) HYCOM CTRL from 19502010.

HYCOM experiments (Fig. 5a). NNI in Exp1 (ITF effect) contributes somewhat to the NNI in CTRL, but it only plays a relatively small role $(r=0.23)$; standard deviation $(\mathrm{STD})=0.1 \mathrm{~K}$ versus STD $=0.4 \mathrm{~K}$ in CTRL. The simulated NNI improves when the surface wind stress effect is included (Exp2, $r=0.43$, STD $=0.14 \mathrm{~K})$, but there are still noticeable discrepancies. By including the effect of turbulent heat flux associated with the surface wind speed anomalies, the simulated NNI in Exp3 is more improved compared to the CTRL, with $r=$ 0.77 and STD $=0.16 \mathrm{~K}$. Therefore, SSTAs of the 


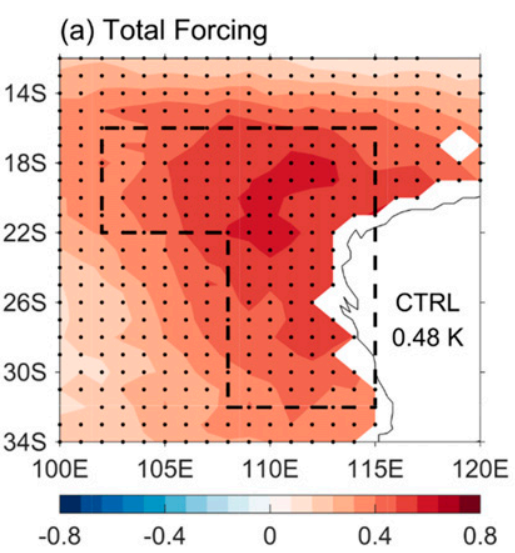

(b) ITF

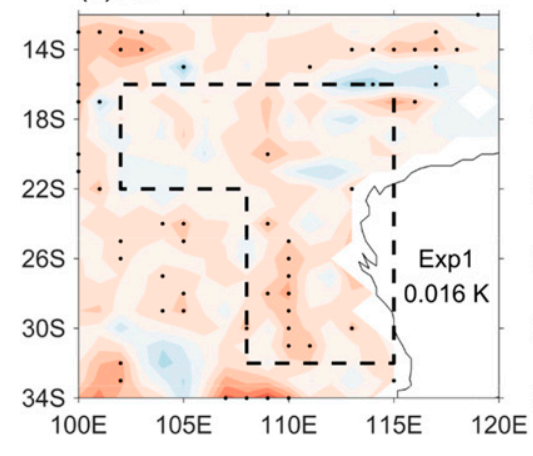

\section{(c) 10 Wstress}

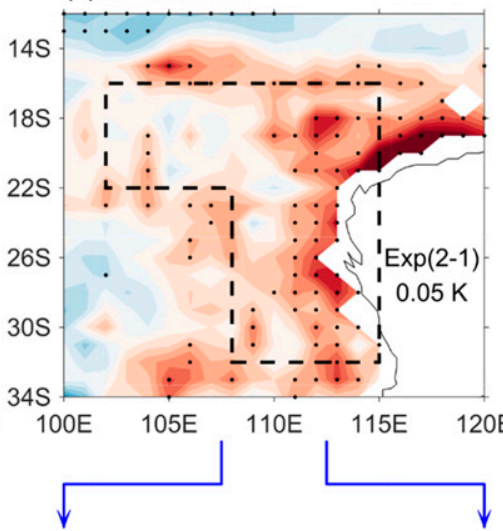

(d) IO Wspeed (LHF)

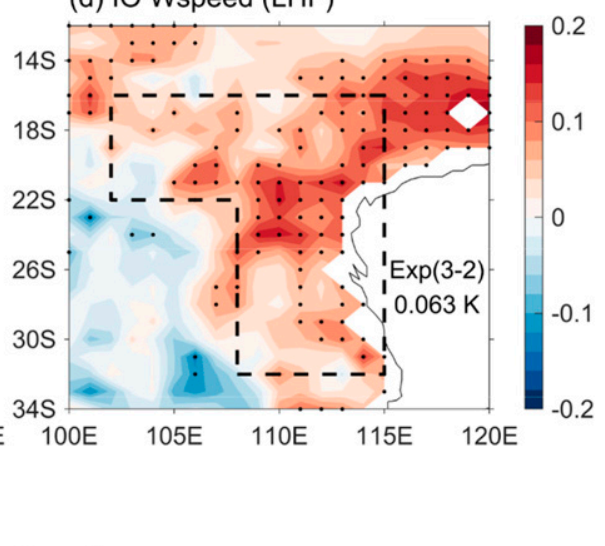

(e) IO Wstress (ENSO)

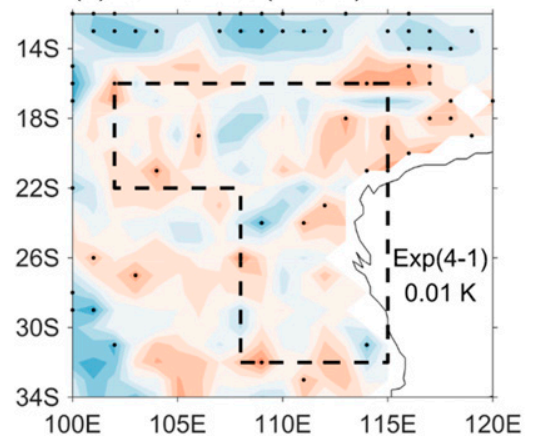

(f) IO Wstress (Local)

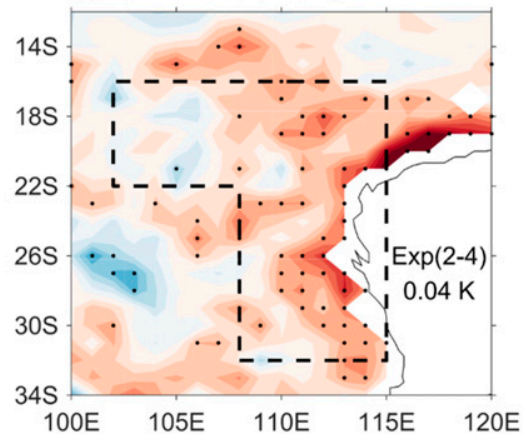

FIG. 3. Regression of DJF SST (K) in HYCOM experiments onto normalized DJF NNI in HYCOM CTRL. Results for (a) HYCOM CTRL, (b) Exp1 (ITF effect), (c) Exp2 - Exp1 (Indian Ocean surface wind stress effect), (d) Exp3 - Exp2 (Indian Ocean surface wind speed effect), (e) Exp4 - Exp1 (Indian Ocean surface wind stress anomalies associated with the ENSO), and (f) Exp2 - Exp4 (Indian Ocean surface wind stress anomalies independent from the ENSO). The stippled area denotes where the regression results are statistically significant at the $90 \%$ confidence level. The regression coefficient averaged over the boxed region is shown at the bottom-right corner in each panel. Note that the color range in (a) is different from those in (b)-(f).

Ningaloo Niño are significantly influenced by the surface heat flux associated with wind speed variation; effects of oceanic dynamical processes induced by local wind stress forcing and the ITF, however, both have significant contributions. It is worth noting that the coastal SST warming during the Ningaloo Niño is underestimated in HYCOM CTRL compared with observations (Fig. 1), which could be due to biases in simulated coastal dynamics associated with unresolved bathymetry. Therefore, the contribution of surface wind stress and ITF effect may be underestimated. This is a potential caveat of this study.

As mentioned above, ENSO can affect the Ningaloo Niño via both oceanic connection (i.e., ITF; Exp1) and 
(a) CTRL (Total Forcing)

\section{SSH regression onto normalized NNI in CTRL}

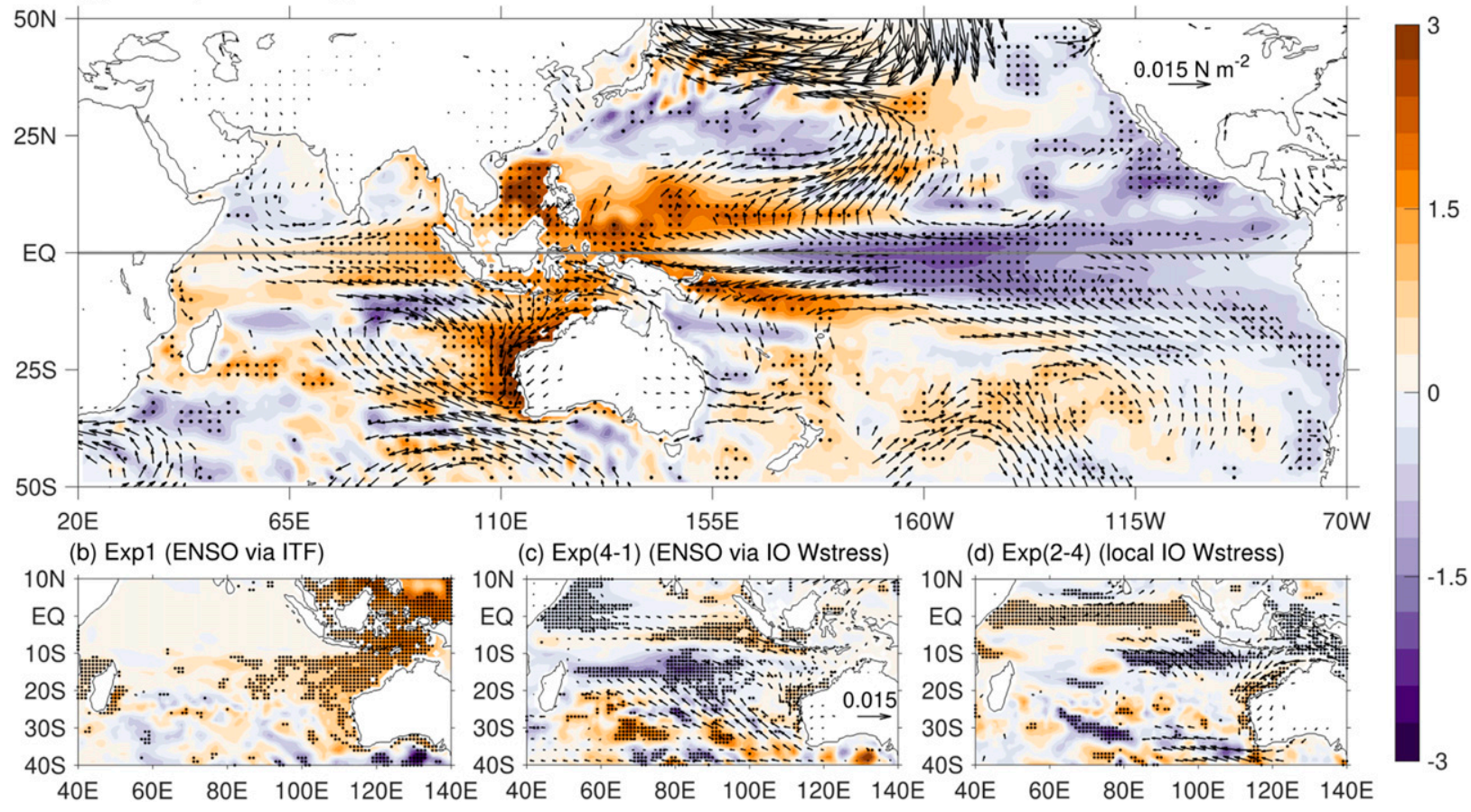

FIG. 4. Regression of DJF SSH (cm) and surface wind stress $\left(\mathrm{N} \mathrm{m}^{-2}\right)$ in HYCOM experiments onto normalized DJF NNI in HYCOM CTRL. Results for (a) HYCOM CTRL, (b) Exp1 (ITF effect), (c) Exp4 - Exp1 (Indian Ocean surface wind stress anomalies associated with ENSO), and (d) Exp2 - Exp4 (Indian Ocean surface wind stress anomalies independent from ENSO). The stippled area denotes where the SSH regression results are statistically significant at the $90 \%$ confidence level. Only significant results at the $90 \%$ confidence level for regression of surface wind stress are shown.

the atmospheric bridge, and the latter is through the effects of ocean dynamics induced by local wind stress forcing (Exp4 - Exp1) and turbulent heat fluxes associated with wind speed (Exp5 - Exp1) (Fig. 5b). Of these three processes, the oceanic connection via ITF plays the most important role in the Ningaloo Niño $(r=$ 0.23 with the CTRL; STD $=0.1 \mathrm{~K}$ ), while the surface wind stress effect is slightly weaker $(r=0.2$; STD $=$ $0.12 \mathrm{~K})$. Changes of the surface heat fluxes associated with the ENSO also play a role $(r=0.11$; STD $=0.11 \mathrm{~K})$. Combining all of these processes, the total ENSO impacts account for an important part of causes for the Ningaloo Niño $(r=0.39$; STD $=0.12 \mathrm{~K})$. There are a total of 10 (10) simulated Ningaloo Niño (Niña) events during the 61-yr HYCOM simulation period, 5 (2) of which were observed to co-occur with the La Niña (El Niño) events. In HadISST (ERSSTv4), 4 (3) out of the total 10 (9) Ningaloo Niño events are accompanied by La Niña events.

\section{c. Surface turbulent heat flux and shortwave radiation}

Note that the combined effect of local wind forcing and the ITF only explains $\sim 40 \%$ of the Ningaloo Niño
SSTA, despite a high correlation $(r=0.77)$ (Figs. 3 and 5a). Hence, other factors that are missing in Exp3 compared to the CTRL also contribute (i.e., changes of the surface turbulent heat flux caused by surface air temperature and specific humidity anomalies, and the surface net shortwave radiation effect associated with cloudiness). These effects are assessed in CTRL - Exp3 (Fig. 6). Given that surface heat fluxes affect the SST tendency, we focus on the anomalies of surface heat fluxes during the developing phase of the Ningaloo Niño (i.e., SON; Fig. S4). It is found that the surface turbulent heat flux anomalies in CTRL - Exp3 are $\sim 1.3$ times as large as the surface net shortwave radiation anomalies (Figs. 6a and 6c). Spatial patterns of the surface turbulent heat flux and the surface shortwave radiation anomalies in CTRL - Exp3 resemble that of SSTA, and they both contribute considerably to SSTAs of the Ningaloo Niño (Figs. 3a and 6). The surface longwave radiation anomalies are negligible (Fig. 6d).

In comparison, positive surface turbulent flux anomalies associated with the surface wind speed effect (Exp3 - Exp2) are evident along the coastal region over northwestern Australia and the subtropical south Indian 
(a) NNI

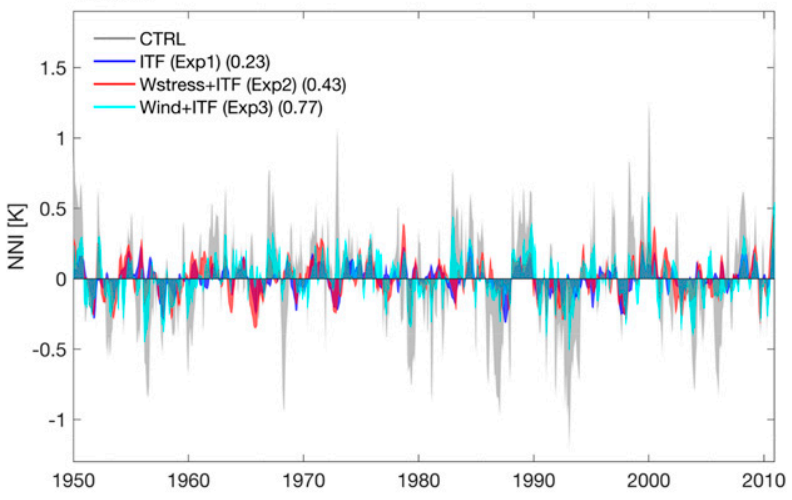

(b) NNI (ENSO impact)

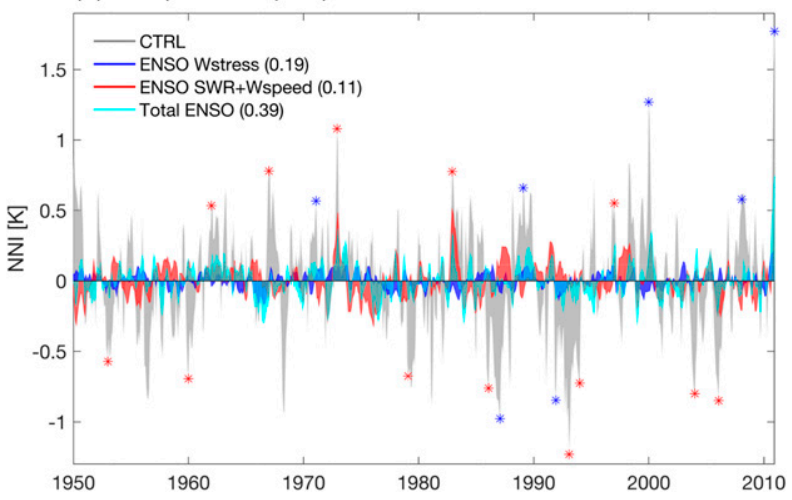

FIG. 5. (a) Time evolution of the NNI anomalies (K) in CTRL (gray), Exp1 (blue), Exp2 (red), and Exp3 (cyan). (b) NNI (K) associated with the ENSO impact. Blue represents the Indian Ocean surface wind stress effect associated with ENSO (Exp4 Exp1). Red is for the effect of surface shortwave radiation and surface wind speed anomalies associated with ENSO (Exp5 - Exp1). Cyan is for total ENSO impact on the NNI (Exp4 + Exp5 - Exp1). Numbers in parentheses represent the correlation coefficient with NNI in CTRL. Asterisks in (b) denote Ningaloo Niño (Niña) events, which are defined as years in which the DJF NNI is greater (smaller) than one (negative) standard deviation. Blue asterisks denote concurrence of Ningaloo Niño (Niña) and La Niña (El Niño) events. Red asterisks are for Ningaloo Niño and Niña alone years.

Ocean (Fig. 6e), which agrees with the spatial pattern of surface wind speed anomalies. In the Ningaloo Niño region, the surface turbulent flux anomalies are small, despite the reduced surface wind speed, which is due to the positive SSTA that tends to increase the surface turbulent heat loss. This is in contrast with the evident positive surface turbulent flux anomalies off the west coast of Australia in CTRL - Exp3, which are caused by surface air temperature and humidity anomalies (Fig. 6a). This result also suggests that positive SSTAs in the Ningaloo Niño region in Exp3 - Exp2 (Fig. 3d) may be caused by transport of warm SSTAs from the North by the Leeuwin Current as well as the Ekman transport off the west coast of Australia, instead of directly caused by the local surface wind speed and surface turbulent flux anomalies.

Corresponding to the positive surface turbulent heat flux anomalies, surface air temperature and specific humidity anomalies are positive with similar spatial patterns to SSTA in the Ningaloo Niño region (Figs. 7c and $7 \mathrm{~d}$ ). Hence, these anomalies could be partially caused by the underlying SST warming. On the other hand, the cyclonic surface wind anomalies weaken the anticyclonic mean surface winds, reducing the advection of the colder and drier air from the Southern Ocean and Australian continent (cf. the mean and anomaly fields in Fig. 7), and therefore may have contributed to the increased air temperature and specific humidity over the warming region. Note that the Ningaloo Niño region is where meridional gradients of surface air temperature and humidity are largest. As shown in Figs. 8 and 9, it is indeed the reduced advection of the colder and drier air (i.e., anomalous wind advecting mean air temperature and humidity) that causes the increased air temperature and specific humidity (Figs. 8c,d and 9c,d) and thus the increased SST. The effect of mean winds advecting anomalous temperature/humidity may spread the positive anomalies of air temperature and humidity to surrounding regions, but does not contribute significantly to the positive anomalies within the Ningaloo Niño region. The effect of anomalous winds advecting anomalous temperature/humidity is weak (Figs. 8a,b,e,f and $9 a, b, e, f)$.

The surface shortwave radiation anomalies also play an important role in causing the SST warming (Fig. 6c). Variability of the surface shortwave radiation is related to variability of the cloud cover (Fig. 10). During the Ningaloo Niño, the total cloud cover decreases off the west Australian coast, which is primarily attributed to the low cloud reduction (Figs. 10e and 10f). The spatial pattern of low cloud cover anomalies is also remarkably similar to that of surface shortwave radiation anomalies over the Ningaloo Niño region (Figs. $6 \mathrm{c}$ and 10f). In contrast, changes in the midlevel cloud are smaller, and the high cloud cover actually increases during the Ningaloo Niño (Figs. 10g and 10h). Causes for the low cloud reduction are related to changes of the large-scale circulation and the underlying SSTA. Climatologically, the southeast Indian Ocean is dominated by low stratiform cloud, which is formed as a result of the stable planetary boundary layer condition associated with the large-scale subsidence and local low SST (Klein and Hartmann 1993). During the Ningaloo Niño, positive SSTAs destabilize the boundary layer, reducing the local cloud cover. In addition, the anomalous low-level cyclonic gyre, which is associated with either the local air-sea 
(a) $Q_{T}$ (air temp \& humidity effect)

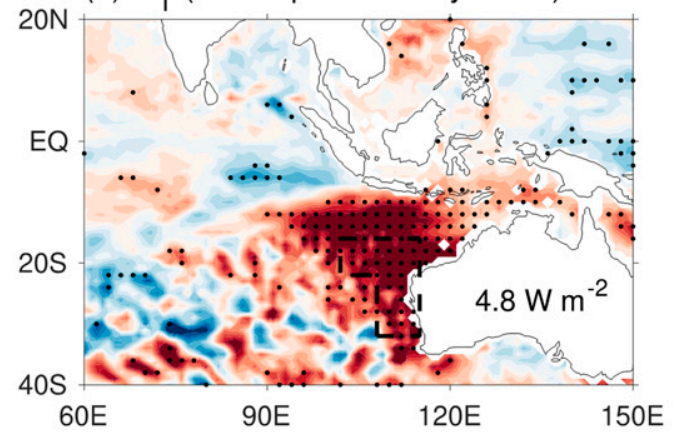

(c) $Q_{\text {swr }}$

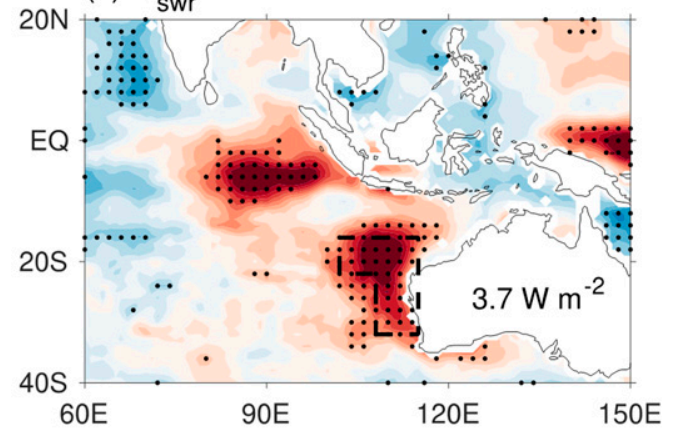

(e) $Q_{T}$ (sfc wind speed effect)

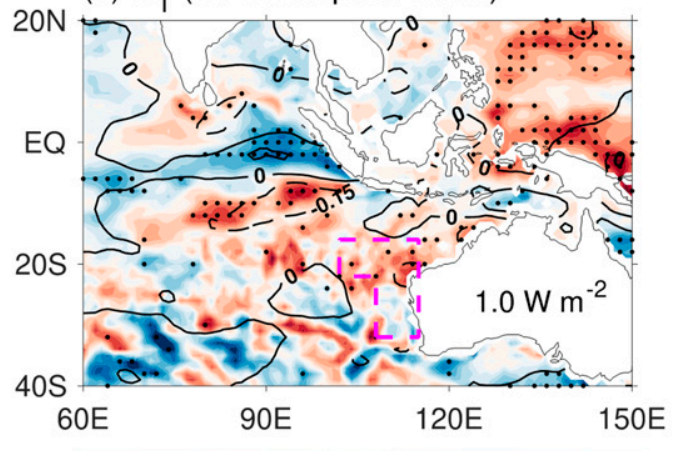

(b) $Q_{R}$

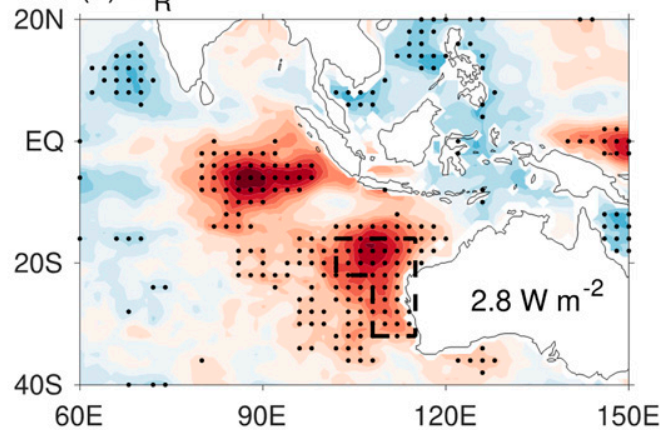

(d) $Q_{\text {Iwr }}$

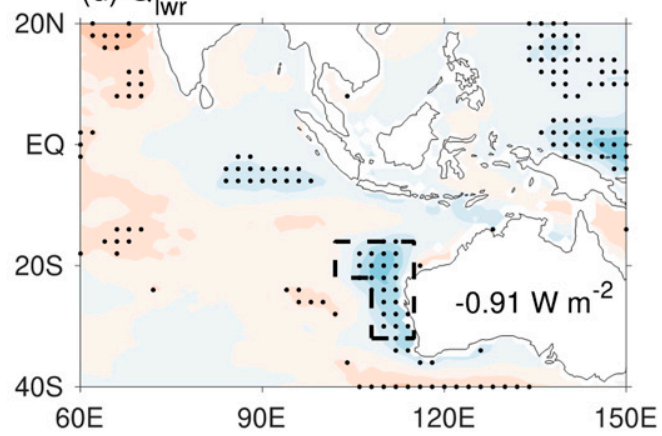

FIG. 6. Regression of SON surface heat fluxes ( $\mathrm{W} \mathrm{m}^{-2}$; positive for downward heat fluxes) onto normalized DJF NNI in HYCOM CTRL. (a) Regression of surface turbulent fluxes in CTRL - Exp3 (caused by surface air temperature and specific humidity anomalies). (b) As in (a), but for surface radiation. (c),(d) Surface shortwave and longwave radiation. (e) Shading denotes regression of surface turbulent flux anomalies in Exp3 - Exp2 (surface wind speed effect). Contours denote the regression of surface wind speed anomalies. The regression coefficient averaged over the boxed region is shown at the bottom-right corner in each panel. Stippled areas denote where the regression results are statistically significant at the $90 \%$ confidence level.

interaction or the remote forcing via the atmospheric bridge, may weaken the mean large-scale subsidence and thus also contributes to the cloud reduction. The reduced cloud cover leads to more incoming shortwave radiation and in turn warms the ocean surface. Hence, the surface shortwave radiation effect is primarily associated with a positive cloud-radiation feedback that amplifies SSTA caused by other physical processes.
It is worth mentioning that in this study, the impacts of surface air temperature and humidity anomalies and anomalous surface shortwave radiation are examined by analyzing CTRL - Exp3. However, having climatological surface air temperature and humidity as boundary conditions in Exp1-Exp3 could artificially damp SSTA, particularly over the tropical ocean interior where a large fraction of surface air temperature and specific humidity anomalies results from SSTA. This could lead 
(a) Mean T2m $[\mathrm{K}]$

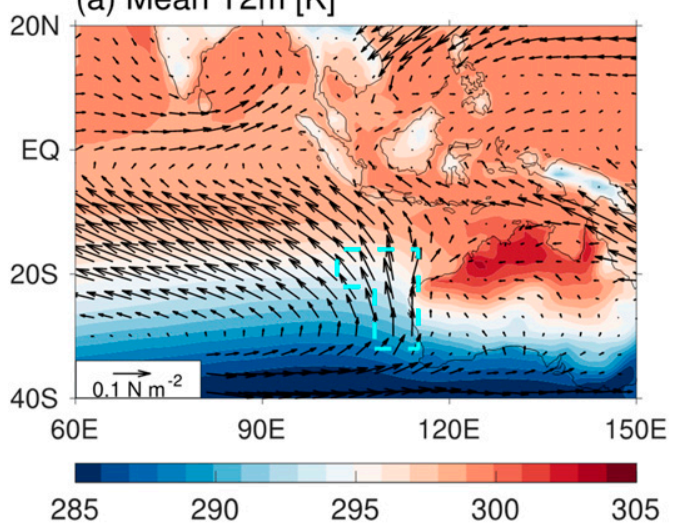

(b) Mean q2m [g/kg]

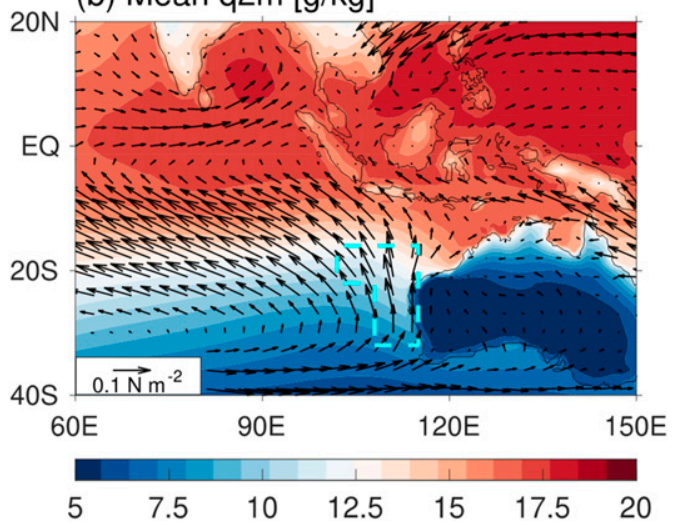

(c) T2m regression

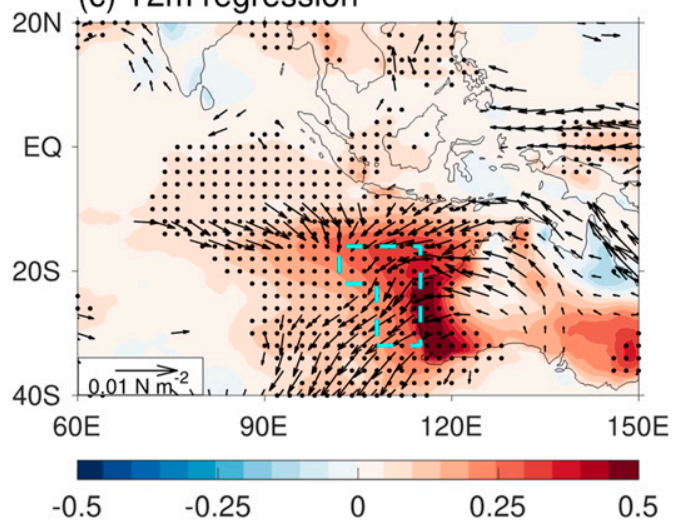

(d) $\mathrm{q} 2 \mathrm{~m}$ regression

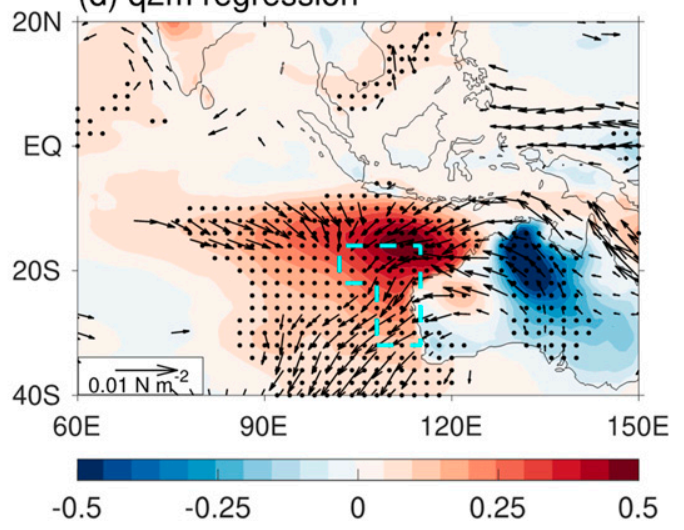

FIG. 7. Seasonal mean (a) 2-m air temperature (K) and (b) specific humidity ( $\mathrm{g} \mathrm{kg}^{-1}$ ) during SON from 1950 to 2010. Vectors represent SON surface wind stress $\left(\mathrm{N} \mathrm{m}^{-2}\right)$. (c), (d) As in (a),(b), but for regression of SON 2-m air temperature, specific humidity, and surface wind stress anomalies onto normalized DJF NNI in CTRL. Stippled areas in (c) and (d) denote where the regression results are statistically significant at the $90 \%$ confidence level.

to smaller SST variability in those experiments and thus exaggerate the SST variability in CTRL - Exp3. In coastal regions such as the west coast of Australia, however, the advection of cold and dry air from land or from the Southern Ocean can indeed force SST variability. Note that CTRL - Exp3 also includes nonlinear effects. Therefore, caution is needed when interpreting results from CTRL - Exp3. Nevertheless, the prominent effects of surface air temperature and humidity anomalies and the cloud-radiation feedback in causing the SSTA of the Ningaloo Niño are clear.

\section{Relative roles of local and remote forcing}

As shown above, both the Indian Ocean intrinsic processes and the remote ENSO forcing via oceanic and atmospheric connections can contribute to the Ningaloo Niño. Indeed, it is found that the Ningaloo Niño is associated with the SST cooling in the central equatorial Pacific (Fig. 11). One interesting feature is that the Ningaloo Niño is more closely associated with SSTAs in the central-western equatorial Pacific, as found in Marshall et al. (2015), which is somewhat more evident in the HYCOM simulation than in observations. A recent study by Zhang and Han (2018) has found that the interbasin interaction between the Ningaloo Niño region and the tropical Pacific plays an important role in causing the out-of-phase SSTA in those two regions.

To characterize the large-scale circulation and precipitation patterns associated with the ENSO-related and ENSO-independent Ningaloo Niños, composite analysis is conducted for the selected Ningaloo Niños for these two categories (Figs. 12 and 13). Five Ningaloo Niño events occurred with the La Niña events, and also five events occurred without (Fig. 5b). Note that the color range for SSTA and the reference length of vectors are different between Figs. 12 and 13. We focus on the relation between the Ningaloo Niño and La Niña, and no further discussions are offered for the Nigaloo Niña and El Niño because of the small sample size (only two years were selected for the concurrence of the Ningaloo Niña and El Niño). 
(a) $u_{m}{ }^{*} T_{a}$

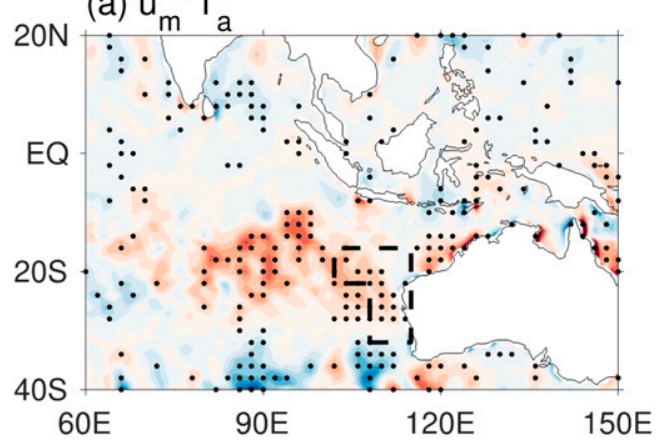

(c) $u{ }^{*} T_{m}$

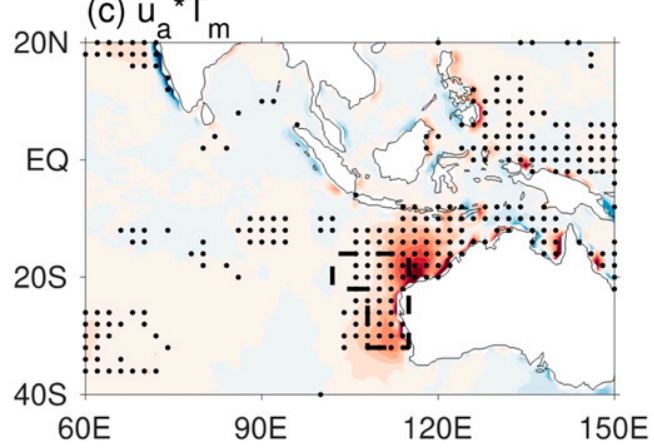

(e) $u_{a}{ }^{*} T_{a}$

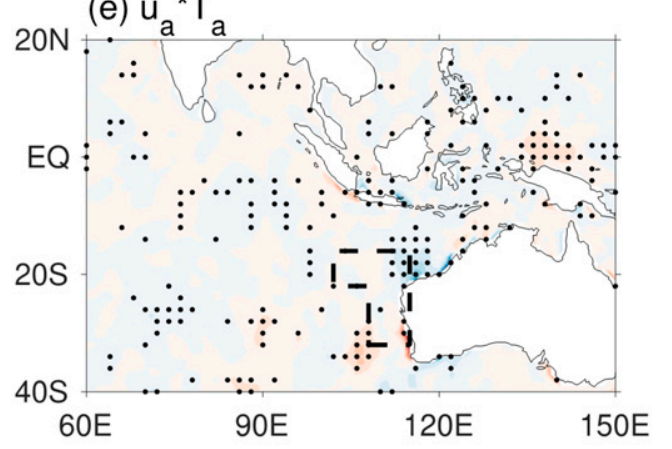

(b) $v_{m}{ }^{*} T_{a}$

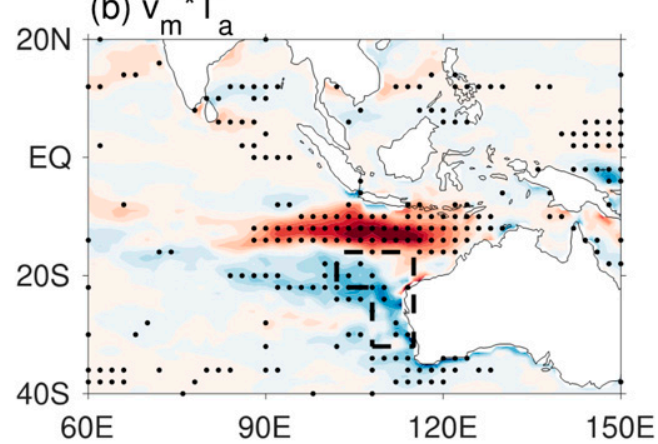

(d) $\mathrm{v}_{\mathrm{a}}{ }^{*} \mathrm{~T}_{\mathrm{m}}$

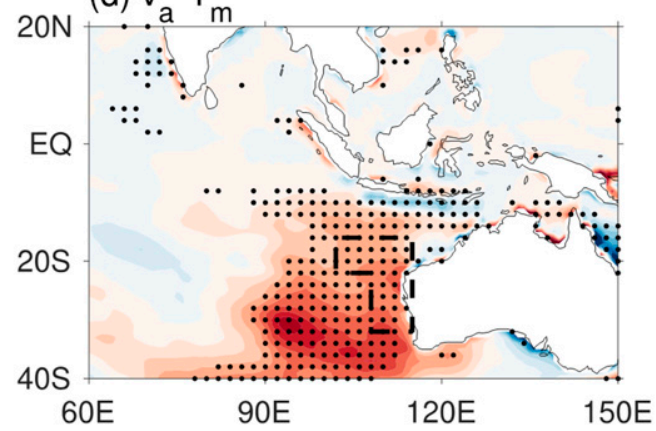

$20 \mathrm{~N}(\mathrm{f}) \mathrm{v}_{\mathrm{a}}{ }^{*} \mathrm{~T}_{\mathrm{a}}$

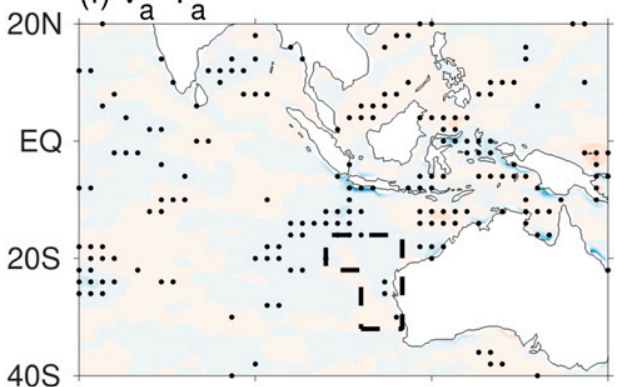

$60 \mathrm{E}$

$90 \mathrm{E}$

$120 \mathrm{E}$

$150 \mathrm{E}$

$\begin{array}{lllllll}-0.15 & -0.1 & -0.05 & 0 & 0.05 & 0.1 & 0.15\end{array}$

FIG. 8. Regression of surface horizontal temperature advection $\left(\mathrm{K} \mathrm{day}^{-1}\right)$ during SON on normalized DJF NNI in CTRL. (a),(b) Advection of surface temperature anomalies by the mean surface wind; (c),(d) advection of mean surface temperature by surface wind anomalies; and (e),(f) advecton of surface temperature anomalies by surface wind anomalies. Stippled areas denote where the regression results are statistically significant at the $90 \%$ confidence level. The mean and anomalous surface winds and temperatures are shown in Fig. 7.

For the Ningaloo Niño events that co-occurred with La Niña, negative SSTA are observed in the central equatorial Pacific, accompanied by enhanced Pacific trade winds and positive (negative) precipitation anomalies over the Maritime Continent (central-eastern equatorial Pacific), a typical situation for developing $\mathrm{La}$ Niña events (Fig. 12). As a Rossby wave response to the enhanced precipitation over the Maritime Continent, anomalous surface cyclonic flow starts to appear over the Ningaloo Niño region in SON and peaks in DJF, causing coastal SST warming through both ocean dynamical processes and increased downward surface heat fluxes as discussed above. The enhanced ITF also contributes to the SST warming (Fig. 3).

By contrast, the composite of Ningaloo Niño events independent of La Niña exhibits very different largescale patterns (Fig. 13). Instead of developing cooling anomalies in the tropical Pacific, weak positive SSTA appear in the central-eastern equatorial Pacific and negative anomalies appear in the western equatorial Pacific. The Pacific Walker circulation is weakened and correspondingly, the convection center shifts eastward, 
(a) $u_{m}^{*} q_{a}$

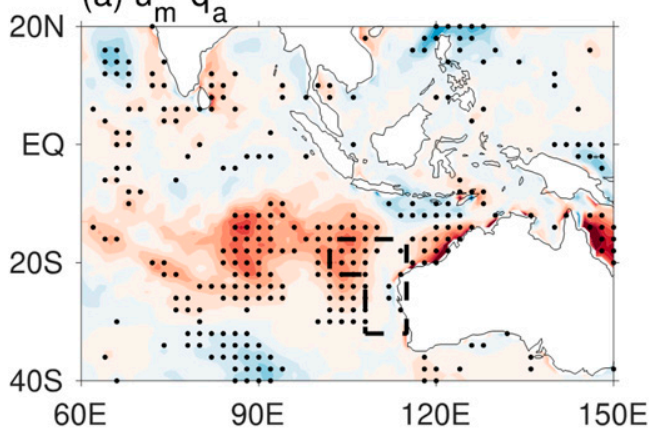

(c) $u_{a}{ }^{*} q_{m}$
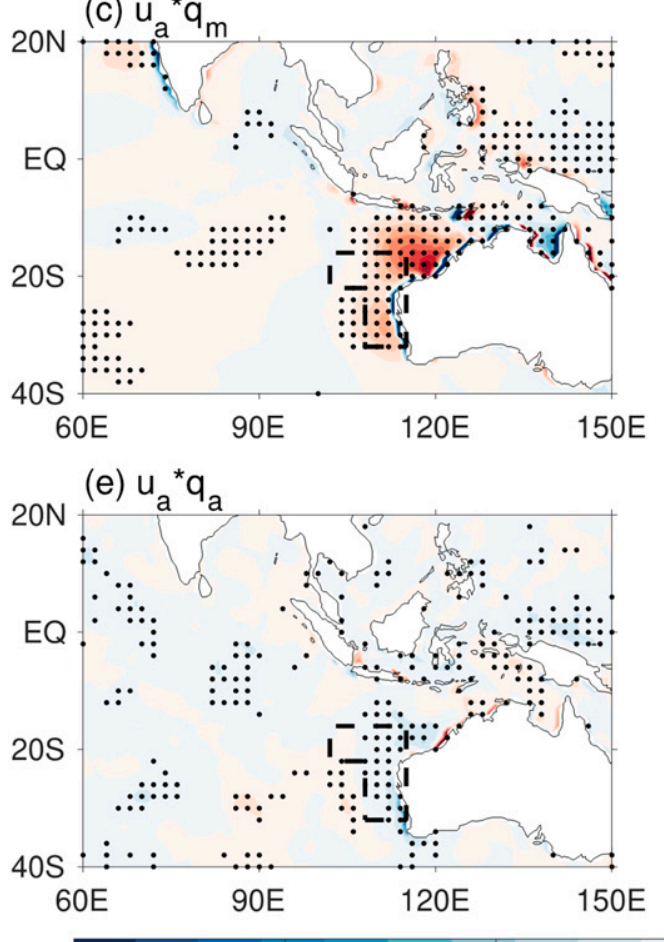

$-0.15$

$-0.05$

\section{$-0.1$}

(b) $v_{m}{ }^{*} q_{a}$

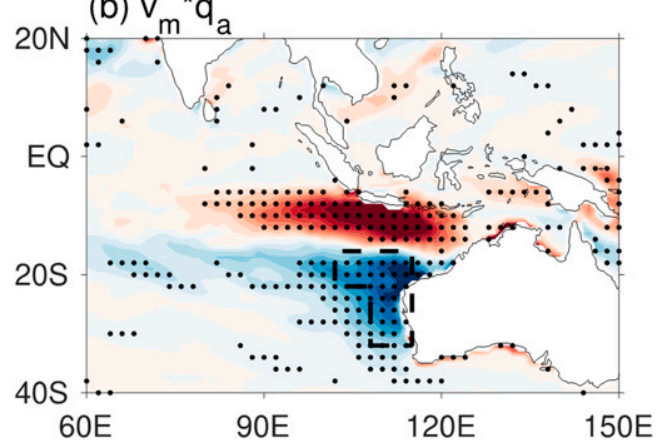

(d) $v_{a}{ }^{*} q_{m}$
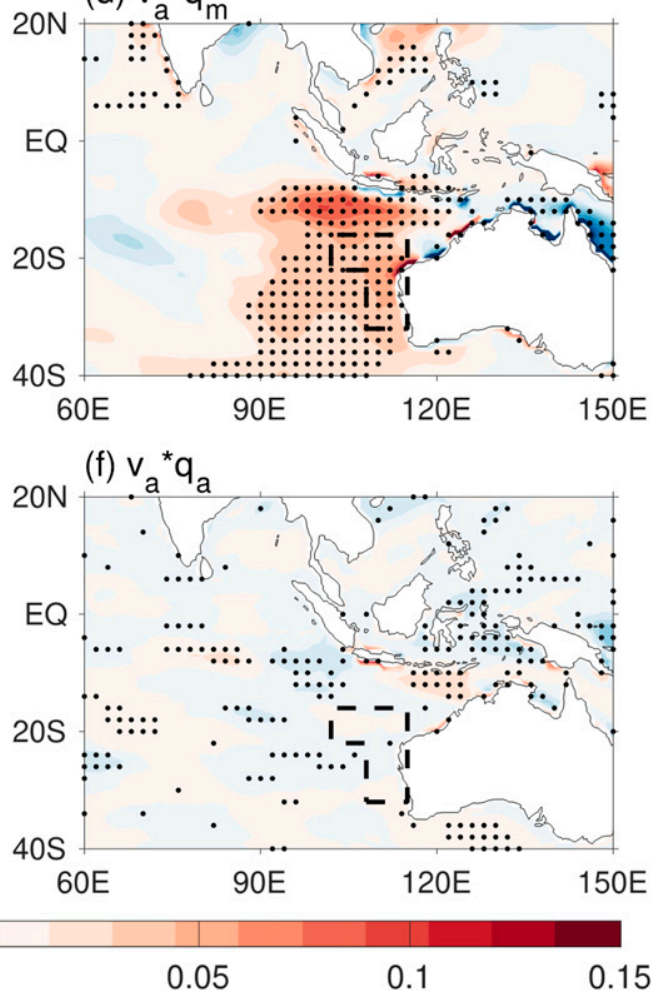

FIG. 9. As in Fig. 8, but for regression of surface horizontal moisture advection $\left(\mathrm{g} \mathrm{kg}^{-1} \mathrm{day}^{-1}\right)$ during SON.

which is opposite to the La Niña conditions. Hence, these Ningaloo Niño events are unlikely to be caused by the Pacific remote forcing. Of particular interest is that coastal northerly wind anomalies appear over the Ningaloo Niño region in both composites (Figs. 12 and 13), even though the SSTA patterns in the tropical Pacific are opposite. This explains the aforementioned negligible regression results of the surface wind stress anomalies over the southeast Indian Ocean associated with the ENSO impact (Fig. 4c); although La Niña indeed generates prominent northerly anomalies off the west coast of Australia (Fig. 12), other processes (discussed below) can also induce a similar wind response over the southeast Indian Ocean even during El Niño (Fig. 13), leading to the overall small Indian Ocean wind anomalies associated with ENSO impact when taking all Ningaloo Niño events into account in the regression analysis.

For La Niña-independent Ningaloo Niño events, pronounced SSTA patterns of IOD are observed in June-August (JJA) and SON, with positive SST and precipitation anomalies occurring over the western tropical Indian Ocean, and negative anomalies occurring off Sumatra (Fig. 13). The associated westward zonal sea level pressure (SLP) gradient induces strong surface easterly anomalies over the equatorial Indian Ocean, which correspond to negative vorticity and anticyclonic wind anomalies over the south Indian 

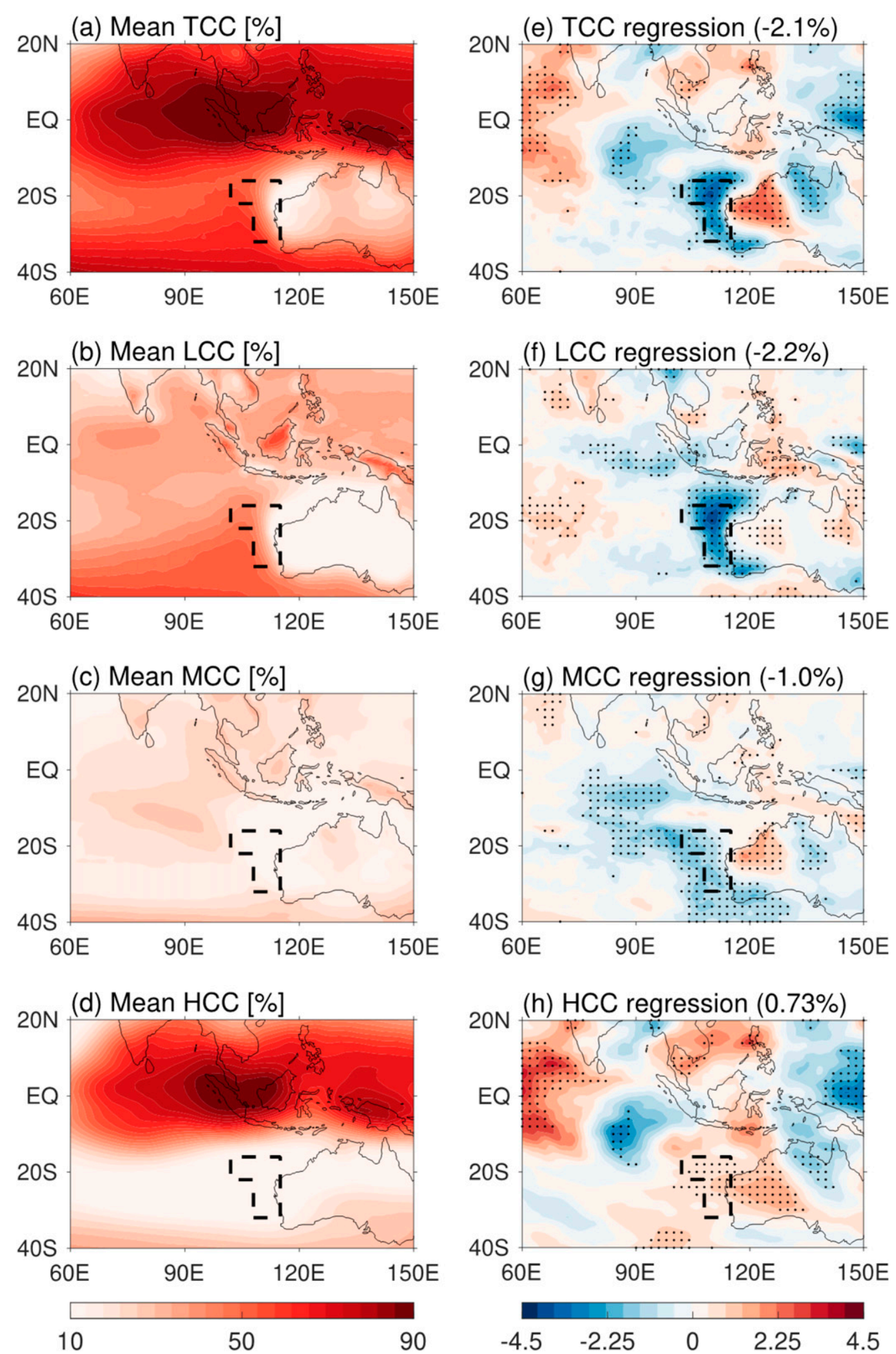

\section{0}

50

90

$\begin{array}{lllll}-4.5 & -2.25 & 0 & 2.25 & 4.5\end{array}$

FIG. 10. Spatial pattern of (a) mean total cloud cover (TCC; \%) during SON and (e) regression of SON TCC onto normalized DJF NNI in HYCOM CTRL. (b),(f) As in (a),(e), but for the low cloud cover (LCC); (c),(g) the midlevel cloud cover (MCC); and (d),(h) the high cloud cover (HCC). Stippled areas in (e)-(h) denote where the regression results are statistically significant at the $90 \%$ confidence level. 
(a) HadISST

SST regressed onto normalized NNI

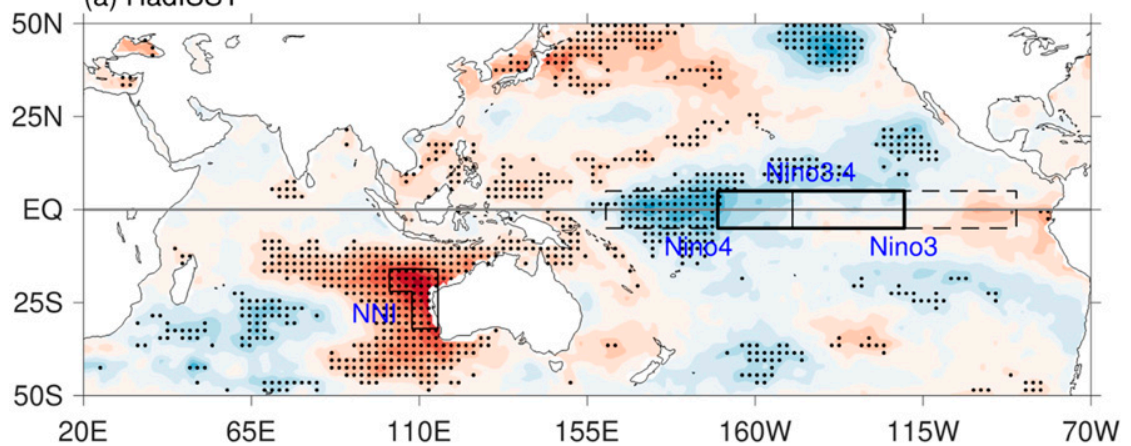

(b) ERSSTv4

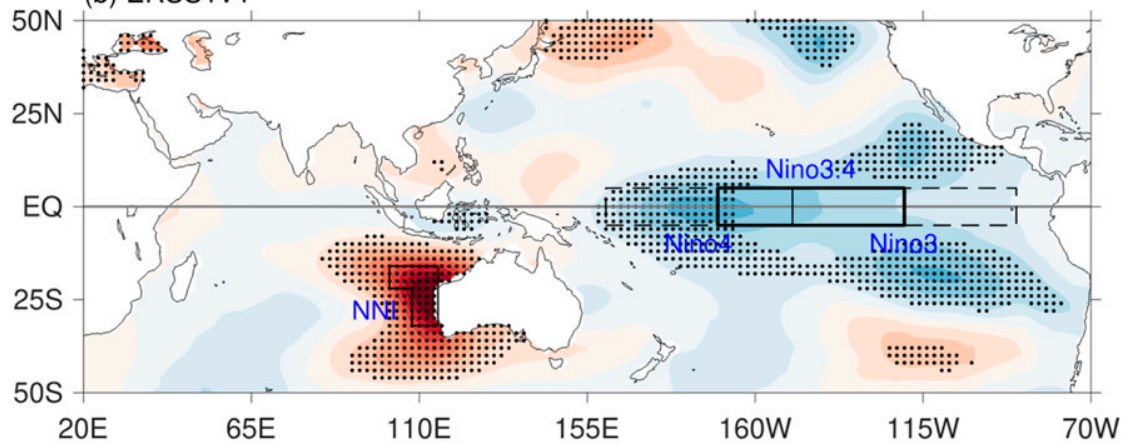

(c) CTRL (Total Forcing)

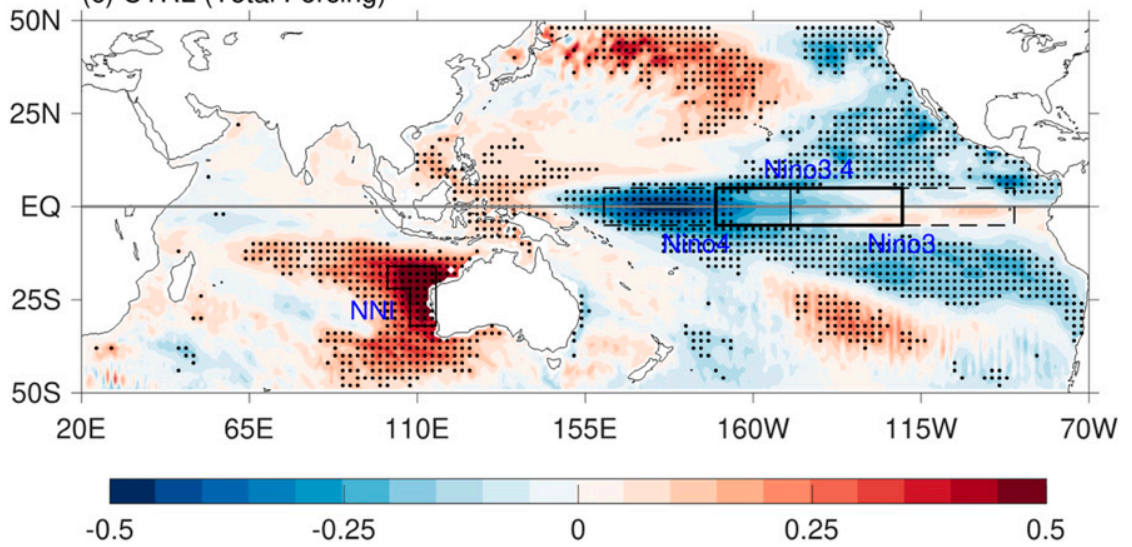

FIG. 11. DJF SST anomalies (K) regressed onto normalized DJF NNI for the 1950-2010 period. Results for (a) HadISST, (b) ERSSTv4, and (c) HYCOM CTRL. Stippled areas denote where the regression results are statistically significant at the $90 \%$ confidence level.

Ocean. At the southern flank of the anomalous anticyclone, northerly anomalies appear off the west coast of Australia, causing local SST warming. Note that the IOD peaks in SON, while the warm SSTAs in the Ningaloo Niño region is sustained and amplified in DJF, which is likely associated with the local airsea interaction processes. SST composites for the HadISST and the ERSSTv4 show similar results (Figs. S5 and S6).

The role of the positive IOD in forcing northerly wind anomalies off the west Australian coast is confirmed by
AGCM experiments (Fig. 14). In response to the eastwest dipole-like SSTA in the tropical Indian Ocean, the model simulates pronounced easterly wind anomalies over the equatorial Indian Ocean and an anticyclonic wind anomaly pattern over the subtropical south Indian Ocean. Consequently, northerly wind anomalies to the south and southwest of the anomalous anticyclone occupy the Ningaloo Niño region, which can cause local SST warming through physical processes discussed in section 3. Note that the warm SSTAs in the Ningaloo Niño region were not included in the AGCM 
Ningaloo Nino with La Nina Composite
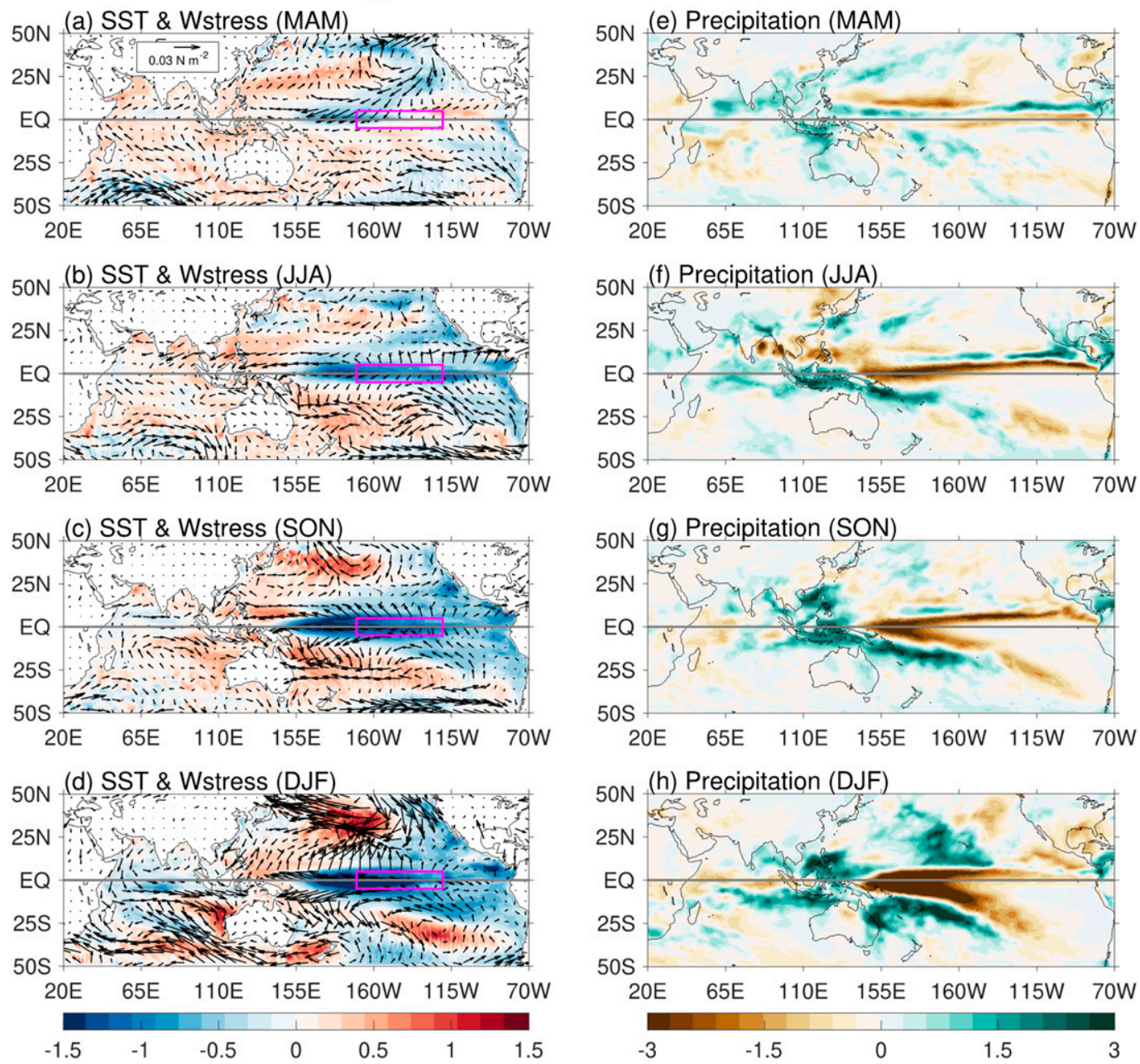

FIG. 12. (a)-(d) Composites of SST (shading; K), surface wind stress anomalies (vectors; $\mathrm{N} \mathrm{m}^{-2}$ ) for five events of Ningaloo Niño with La Niña years. See Fig. 5 for selected years. (a) March-May, (b) June-August, (c) SeptemberNovember, and (d) December-February. The boxed region denotes the Niño-3.4 region $\left(5^{\circ} \mathrm{N}-5^{\circ} \mathrm{S}, 170^{\circ}-120^{\circ} \mathrm{W}\right)$. (e)-(h) As in (a)-(d), but for precipitation anomalies $\left(\mathrm{mm} \mathrm{day}^{-1}\right)$.

experiments (Figs. 14a and 14b); therefore, northerly wind anomalies off the west coast of Australia are not caused by the local SST warming. There are also noticeable discrepancies between AGCM results and observations. For instance, the largest northerly wind anomalies over the south Indian Ocean are located along the coastal area during the Ningaloo Niño in observations (Figs. 13c and 13d), while no such feature can be seen in AGCM results (Fig. 14). Such a discrepancy may be due to excluding SSTA in the Ningaloo Niño region and lack of air-sea interaction processes in AGCM, which can amplify northerly wind anomalies off the west coast of Australia. Ashok et al. (2003) also found a prominent impact of the positive IOD on Australian rainfall and atmospheric circulation using AGCM experiments, but they focus on the austral winter season.

Results above suggest that both La Niña and the positive IOD may cause the Ningaloo Niño. Indeed, approximately $40 \%$ of the historical Ningaloo Niño events were observed to co-occur with La Niña, and $30 \%$ occurred in conjunction with positive IOD events (Fig. 15), despite some cross-data differences and model/data discrepancies. (The selected years are listed in Table S1.) However, $30 \%$ of Ningaloo Niño events are independent of both La Niña and positive IOD, for which the cause may involve other climate phenomena, such as the Madden-Julian oscillation (MJO; Madden and Julian 1971; Zhang et al. 2017) and variations of the Australian monsoon. It appears that more Ningaloo 


\section{Ningaloo Nino without La Nina Composite}

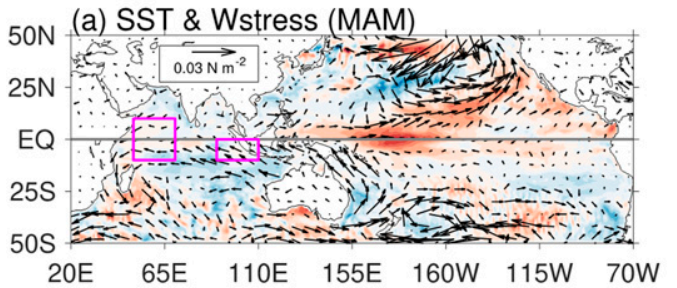

(e) Precipitation (MAM)
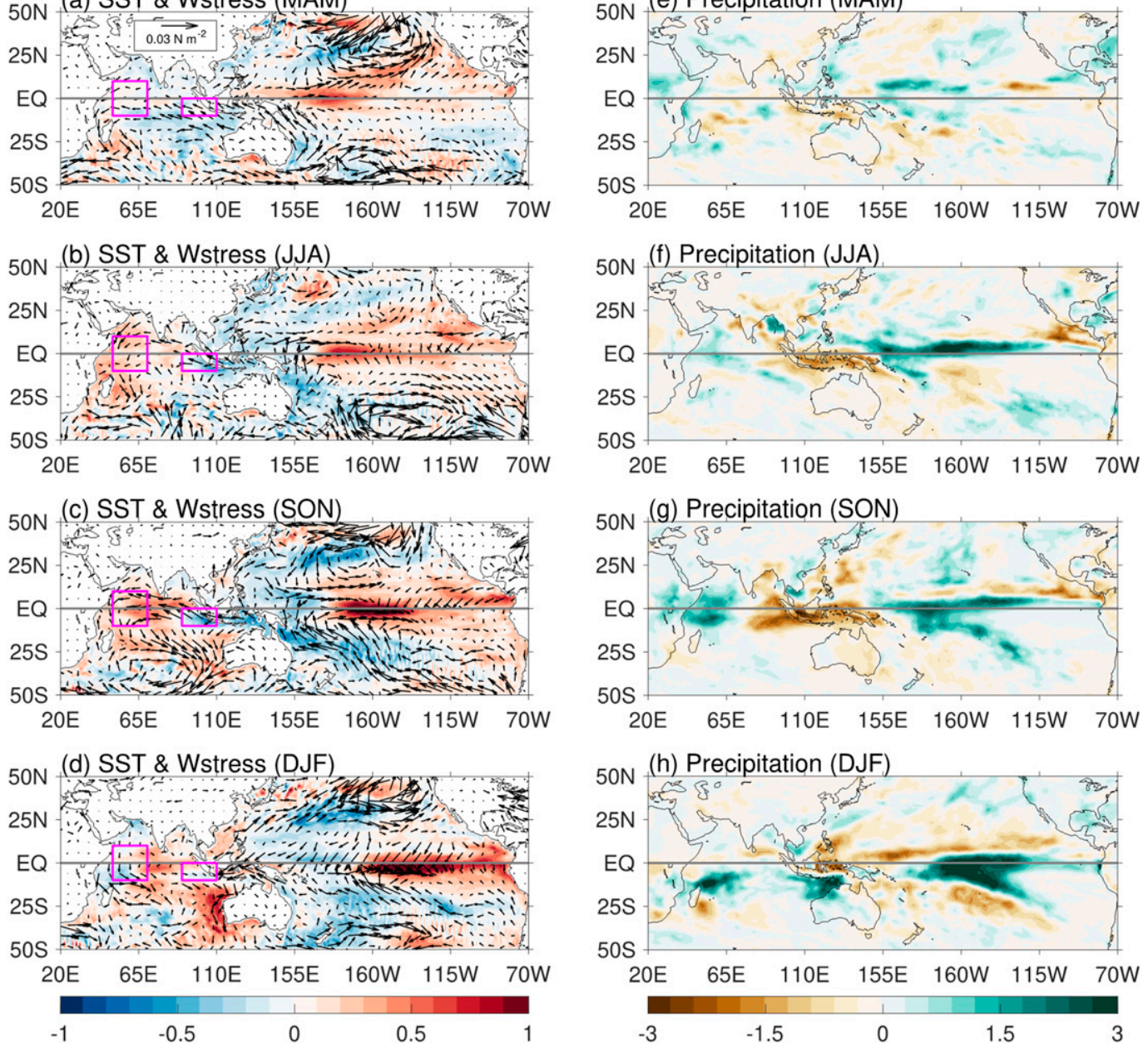

FIG. 13. As in Fig. 12, but for five events of Ningaloo Niño without La Niña years. Boxed regions in (a)-(d) denote domains used to calculate the DMI $\left(10^{\circ} \mathrm{S}-10^{\circ} \mathrm{N}, 50^{\circ}-70^{\circ} \mathrm{E}\right.$ and $\left.10^{\circ} \mathrm{S}-0^{\circ}, 90^{\circ}-110^{\circ} \mathrm{E}\right)$. Note that the color range and vector reference length in (a)-(d) are different from those in Fig. 12.

Niño events are associated with La Niña during recent decades, which may be related to the recent transition of the interdecadal Pacific oscillation (IPO) from a positive to a negative phase (Zhang 2016; Zhang et al. 2018) that favors formation of the Ningaloo Niño (Feng et al. 2015). Consistently, Doi et al. (2015) find that the predictability of rainfall anomalies off the west coast of Australia increases in recent decades because of higher local SST in the Ningaloo Niño region, which is also partly attributed to the IPO impact.

Composites of the DJF NNI in the HYCOM experiments show that surface winds play an important role in causing the Ningaloo Niño, whether or not it co-occurs with La Niña or positive IOD (Fig. 16). This is consistent with the prominent surface wind effect found in section 3 b. On the other hand, the ITF effect varies substantially among different composites. During La Niña years, the enhanced ITF contributes prominently to the Ningaloo Niño; during positive IOD years, the ITF effect actually weakens the Ningaloo Niño, which may be associated with westerly anomalies over the tropical Pacific, as found in observations and AGCM experiments (not shown) that weaken the ITF. During Ningaloo Niño alone years, the ITF effect is negligible. This explains why the total ITF effect on the Ningaloo Niño is small (Figs. 3b and 5a), although it plays an important role in the Ningaloo Niño that co-occurred with La Niña. Note that biases in simulated coastal dynamics may underestimate the surface wind stress and ITF effects. Nevertheless, these results suggest that physical processes that generate the Ningaloo Niño vary from event to event. It is also notable that the surface temperature 


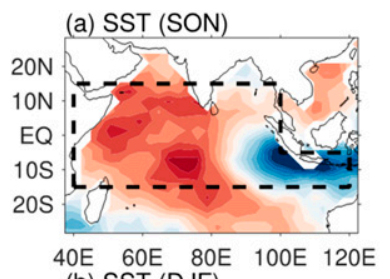

(b) SST (DJF)

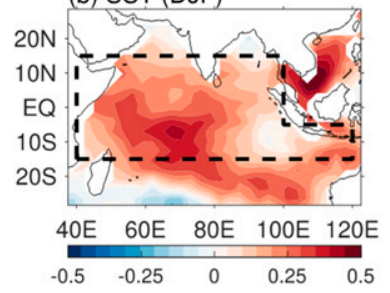

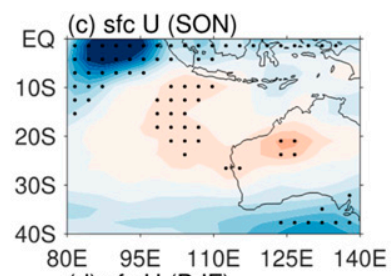

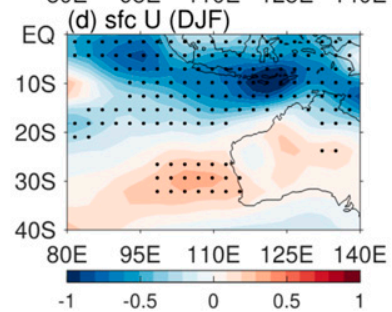

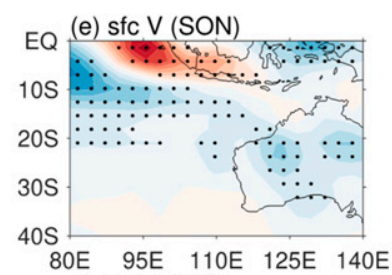

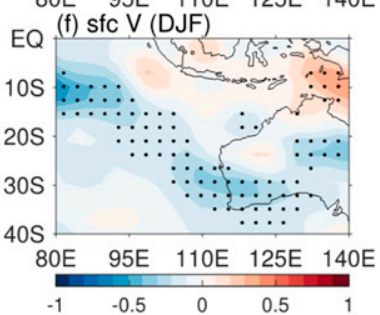

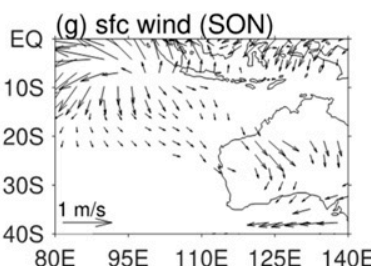

(h) sfc wind (DJF)

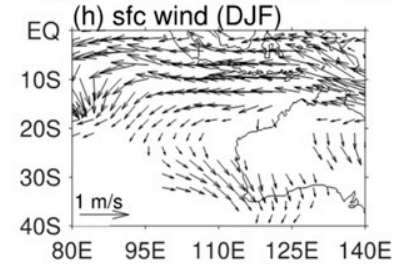

FIG. 14. AGCM results that show the role of positive IOD in forcing northerly wind anomalies off the west coast of Australia. (a),(b) SSTA (K) associated with positive IOD during SON and DJF, derived from observational composite. The monthly SSTA of a 2-yr period within the region surrounded by the dashed line is directly added to monthly SST climatology in the AGCM experiments. (c),(d) Surface zonal wind anomalies $\left(\mathrm{m} \mathrm{s}^{-1}\right)$ forced by positive IOD. (e),(f) Surface meridional wind anomalies. Stippled areas in (c)-(f) denote where the regression results are statistically significant at the $90 \%$ confidence level. (g),(h) Surface wind anomalies, which are statistically significant at the $90 \%$ confidence level.

and humidity effects as well as the surface radiation play important roles in causing the Ningaloo Niño. However, part of this contribution is associated with the positive cloud-radiation feedback, which is an amplification mechanism that requires initial perturbation triggered by other processes, such as the ITF effect and the surface wind anomalies.

\section{Summary and discussion}

Generation and development mechanisms of the austral summer SST warming surge off the west Australian coast (i.e., the Ningaloo Niño) are investigated through OGCM and AGCM experiments. During the Ningaloo Niño, large-scale surface cyclonic wind anomalies appear over the south Indian Ocean. The associated strong northerly wind anomalies over the Ningaloo Niño region weaken the mean surface wind speed and thereby reduce the surface turbulent heat flux, causing local SST warming. Meanwhile, northerly wind stress anomalies also strengthen the Leeuwin Current and weaken the coastal upwelling, contributing to the positive SSTA, especially in the coastal region. The enhanced ITF also helps to enhance the SST warming, but this effect is important only during La Niña events. These findings are basically in line with previous studies (Kataoka et al. 2014; Feng et al. 2013; Tozuka et al. 2014; Marshall et al. 2015). Recently, Kataoka et al. (2017) found that the reduced mixed layer depth (MLD) in the Ningaloo Niño region enhances the cooling effect of the total latent heat flux and the warming effect of the total shortwave radiation. In this study, we mainly focused on the anomalies of surface heat fluxes, but we also found a shallower MLD during the Ningaloo Niño (not shown), which could contribute to the positive SSTA.

Our analysis further reveals substantial contributions of surface shortwave radiation anomalies and surface turbulent heat flux anomalies induced by surface air temperature and specific humidity changes to the Ningaloo Niño. Aforementioned northerly and northwesterly anomalies off the west coast of Australia effectively reduce the transport of cold and dry air from the Southern Ocean to the Ningaloo Niño region. As a result, the coastal surface air becomes relatively warm and humid, which reduces the air-sea temperature and humidity gradient and thereby decreases the surface turbulent heat fluxes, contributing to the SST warming. The surface shortwave radiation increases during the Ningaloo Niño because of the low-level cloud cover reduction. The southeast Indian Ocean is dominated by the low stratiform cloud climatologically caused by the stable boundary layer condition. During the Ningaloo Niño, the warm SSTAs and large-scale low-level cyclonic wind anomalies destabilize the atmospheric boundary layer, leading to the decrease in the cloud cover and increase in the surface shortwave radiation, which further amplifies the warm SSTAs. This loop of processes provides a positive cloudradiation feedback for the growth of the ocean and atmospheric anomalies of the Ningaloo Niño.

The relative role of local and remote forcing in causing the Ningaloo Niño is investigated. It is found that both the Indian Ocean intrinsic processes and the remote ENSO forcing may contribute to the generation 
(a) HadISST

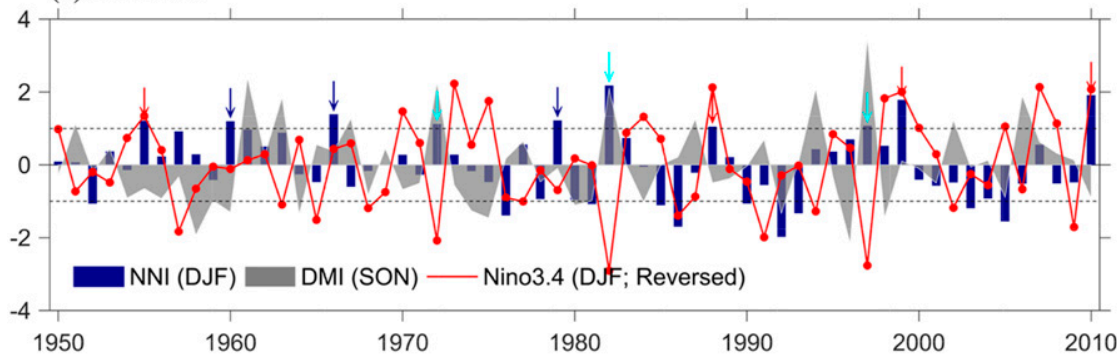

(b) ERSSTv4

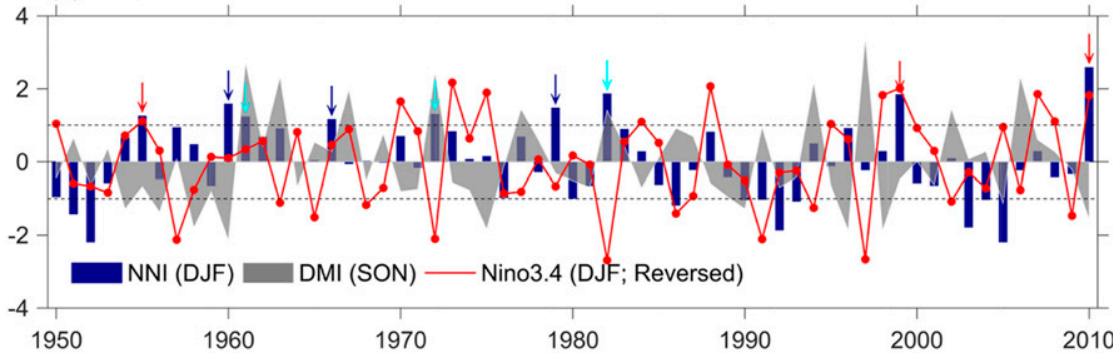

(c) HYCOM CTRL

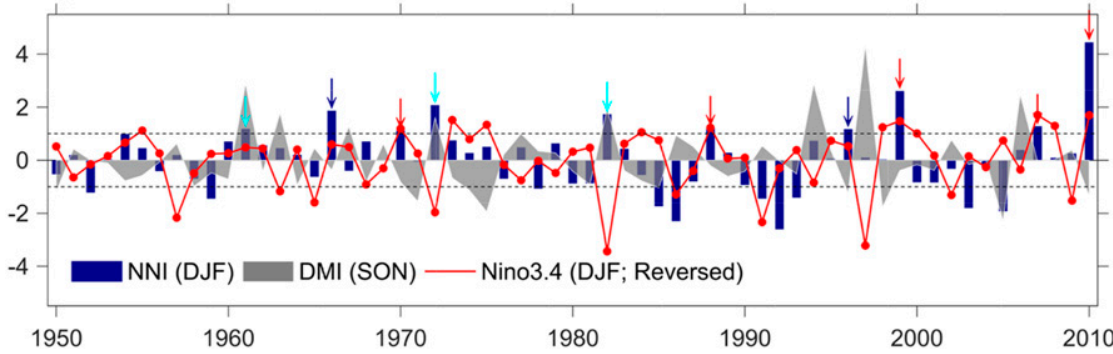

FIG. 15. Time evolution of the DJF NNI (blue bar), reversed DJF Niño-3.4 index (red line), and SON DMI (gray shading). Results for (a) HadISST, (b) ERSSTv4, and (c) CTRL. All three indices are normalized by their standard deviation over the analysis period. Arrows denote the Ningaloo Niño events. Red arrows denote concurrence of the Ningaloo Niño and La Niña, cyan is for concurrence of the Ningaloo Niño and positive IOD, and blue is for Ningaloo Niño alone years. (See Table S1 in the supplemental material for selected years.)

and development of the Ningaloo Niño. During the analysis period, La Niña events play important roles in approximately $40 \%$ of total Ningaloo Niño events. The remaining Ningaloo Niño events occurred independently of La Niñas, and half of these events were associated with the positive Indian Ocean dipole (IOD). During the positive IOD, warm (cold) SSTA and positive (negative) precipitation anomalies over the western (eastern) tropical Indian Ocean drive pronounced equatorial easterly wind anomalies, which correspond to negative vorticity and anticyclonic wind anomalies over the south Indian Ocean. Associated northerly wind anomalies at the southern flank of the anomalous anticyclone occupy the Ningaloo Niño region, which may cause local SST warming. After the IOD peak in SON, the local air-sea interaction continues to take effect and further amplifies the positive SSTA and northerly wind anomalies over the Ningaloo Niño region. The role of the positive IOD in causing northerly wind anomalies off the west coast of Australia is confirmed by AGCM experiments.

During $1950-2010,70 \%$ of total Ningaloo Niño events are associated with ENSO and IOD. This suggests that other factors may also contribute to the Ningaloo Niño, such as the Madden-Julian oscillation (MJO). Future studies targeting other causes of the Ningaloo Niño are needed. It is also interesting to note that not every positive IOD event can trigger the Ningaloo Niño, which could be related to the different spatial patterns of SSTA during different IOD events. This will be the subject of a forthcoming study.

Acknowledgments. Lei Zhang and W. Han are supported by NSF OCE 1658132 and NASA Physical 


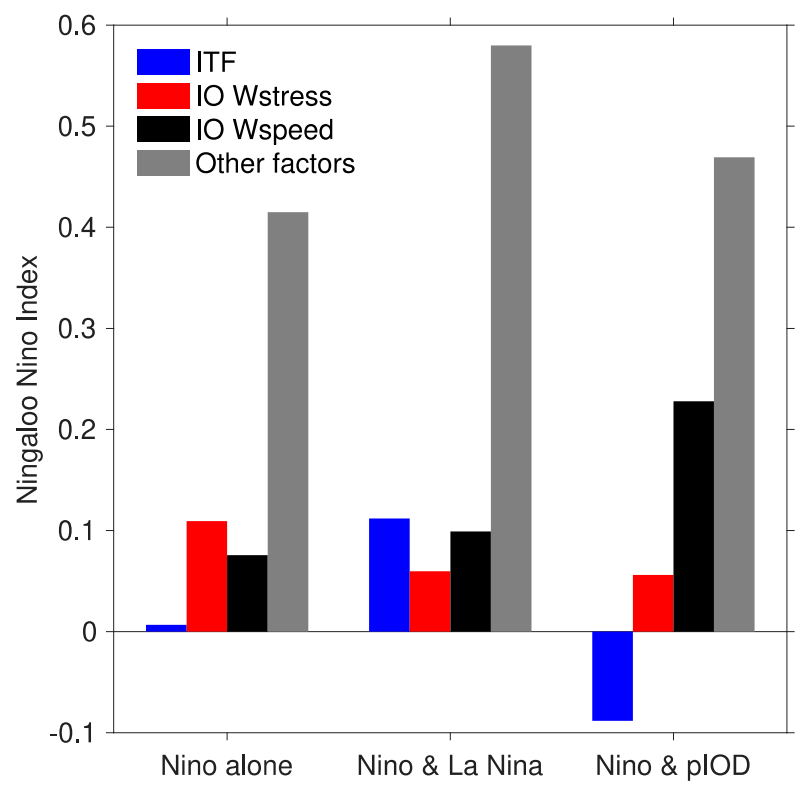

FIG. 16. Composites of DJF NNI anomalies (K) in Exp1 (ITF effect, blue), Exp2 - Exp1 (surface wind stress effect, red), and Exp3 - Exp2 (surface wind speed effect, black). Gray bars denote other factors, including turbulent flux anomalies associated with surface temperature and humidity effects as well as surface radiation (CTRL - Exp3). First column shows results for Ningaloo Niño alone years, the second shows results for the Ningaloo Niño with La Niña, and the third shows results for the Ningaloo Niño with positive IOD. See Fig. 12 (and Table S1) for selected years.

Oceanography Program Award NNX17AH25G. T Shinoda is supported by NSF Grants OCE-1658218 and AGS-1347132, NASA Grant NNX17AH25G, and NOAA Grants NA15OAR431074 and NA17OAR4310256.

\section{REFERENCES}

Ashok, K., Z. Guan, and T. Yamagata, 2003: Influence of the Indian Ocean Dipole on the Australian winter rainfall. Geophys. Res. Lett., 30, 4499, https://doi.org/10.1029/2003GL017926.

Benthuysen, J., M. Feng, and L. Zhong, 2014: Spatial patterns of warming off Western Australia during the 2011 Ningaloo Niño: Quantifying impacts of remote and local forcing. Cont. Shelf Res., 91, 232-246, https://doi.org/10.1016/j.csr.2014.09.014.

Bleck, R., 2002: An oceanic general circulation model framed in hybrid isopycnic-Cartesian coordinates. Ocean Modell., 4, 5588, https://doi.org/10.1016/S1463-5003(01)00012-9.

Carton, J. A., and B. S. Giese, 2008: A reanalysis of ocean climate using Simple Ocean Data Assimilation (SODA). Mon. Wea. Rev., 136, 2999-3017, https://doi.org/10.1175/ 2007MWR1978.1.

Clarke, A. J., and X. Liu, 1994: Interannual sea level in the northern and eastern Indian Ocean. J. Phys. Oceanogr., 24, 1224-1235, https://doi.org/10.1175/1520-0485(1994)024<1224: ISLITN $>2.0 . \mathrm{CO} ; 2$.

Depczynski, M., and Coauthors, 2013: Bleaching, coral mortality and subsequent survivorship on a West Australian fringing reef. Coral Reefs, 32, 233-238, https://doi.org/10.1007/ s00338-012-0974-0.
Deser, C., A. S. Phillips, and M. A. Alexander, 2010: Twentieth century tropical sea surface temperature trends revisited. Geophys. Res. Lett., 37, L10701, https://doi.org/10.1029/ 2010 GL043321.

Doi, T., S. K. Behera, and T. Yamagata, 2013: Predictability of the Ningaloo Niño/Niña. Sci. Rep., 3, 1, https://doi.org/10.1038/ srep02892.

,$- \ldots$, and - 2015: An interdecadal regime shift in rainfall predictability related to the Ningaloo Niño in the late 1990s. J. Geophys. Res. Oceans, 120, 1388-1396, https://doi.org/ 10.1002/2014JC010562.

Duncan, B. T., and W. Han, 2009: Indian Ocean intraseasonal sea surface temperature variability during boreal summer: Madden-Julian Oscillation versus submonthly forcing and processes. J. Geophys. Res., 114, C05002, https://doi.org/ 10.1029/2008JC004958.

Fairall, C. W., E. F. Bradley, J. E. Hare, A. A. Grachev, and J. B. Edson, 2003: Bulk parameterization of air-sea fluxes: Updates and verification for the COARE algorithm. J. Climate, 16, 571-591, https://doi.org/10.1175/1520-0442(2003)016<0571: BPOASF $>2.0 . \mathrm{CO} ; 2$.

Feng, M., S. Wijffels, S. Godfrey, and G. Meyers, 2005: Do eddies play a role in the momentum balance of the Leeuwin Current? J. Phys. Oceanogr., 35, 964-975, https://doi.org/10.1175/JPO2730.1.

_ - M. J. McPhaden, S.-P. Xie, and J. Hafner, 2013: La Niña forces unprecedented Leeuwin Current warming in 2011. Sci. Rep., 3, 1277, https://doi.org/10.1038/srep01277.

—, H. H. Hendon, S.-P. Xie, A. G. Marshall, A. Schiller, Y. Kosaka, N. Caputi, and A. Pearce, 2015: Decadal increase in Ningaloo Niño since the late 1990s. Geophys. Res. Lett., 42, 104-112, https://doi.org/10.1002/2014GL062509.

Fu, X., B. Wang, T. Li, and J. P. McCreary, 2003: Coupling between northward-propagating, intraseasonal oscillations and sea surface temperature in the Indian Ocean. J. Atmos. Sci., 60, 1733-1753, https://doi.org/10.1175/1520-0469(2003)060<1733: CBNIOA $>2.0 . \mathrm{CO} ; 2$.

Furue, R., J. P. McCreary, J. Benthuysen, H. E. Phillips, and N. L. Bindoff, 2013: Dynamics of the Leeuwin Current: Part 1. Coastal flows in an inviscid, variable-density, layer model. Dyn. Atmos. Oceans, 63, 24-59, https://doi.org/10.1016/ j.dynatmoce.2013.03.003.

Gill, A. E., 1980: Some simple solutions for heat-induced tropical circulation. Quart. J. Roy. Meteor. Soc., 106, 447-462, https:// doi.org/10.1002/qj.49710644905.

Han, W., 2005: Origins and dynamics of the 90-day and 30-60-day variations in the equatorial Indian Ocean. J. Phys. Oceanogr., 35, 708-728, https://doi.org/10.1175/JPO2725.1.

_, D. Yuan, W. T. Liu, and D. J. Halkides, 2007: Intraseasonal variability of Indian Ocean sea surface temperature during boreal winter: Madden-Julian Oscillation versus submonthly forcing and processes. J. Geophys. Res., 112, C04001, https:// doi.org/10.1029/2006JC003791.

_ G. A. Meehl, A. Hu, J. Zheng, J. Kenigson, J. Vialard, B. Rajagopalan, and Yanto, 2017: Decadal variability of the Indian and Pacific Walker cells since the 1960s: Do they covary on decadal time scales? J. Climate, 30, 8447-8468, https://doi.org/ 10.1175/JCLI-D-16-0783.1.

Hendon, H. H., and G. Wang, 2010: Seasonal prediction of the Leeuwin Current using the POAMA dynamical seasonal forecast model. Climate Dyn., 34, 1129-1137, https://doi.org/ 10.1007/s00382-009-0570-3.

Huang, B., and Coauthors, 2015: Extended Reconstructed Sea Surface Temperature Version 4 (ERSST.v4). Part I: Upgrades 
and intercomparisons. J. Climate, 28, 911-930, https://doi.org/ 10.1175/JCLI-D-14-00006.1.

Jia, F., L. Wu, and B. Qiu, 2011: Seasonal modulation of eddy kinetic energy and its formation mechanism in the southeast Indian Ocean. J. Phys. Oceanogr., 41, 657-665, https://doi.org/ 10.1175/2010JPO4436.1.

Kara, A. B., H. E. Hurlburt, and A. J. Wallcraft, 2005: Stabilitydependent exchange coefficients for air-sea fluxes. J. Atmos. Oceanic Technol., 22, 1080-1094, https://doi.org/10.1175/ JTECH1747.1.

Kataoka, T., T. Tozuka, S. Behera, and T. Yamagata, 2014: On the Ningaloo Niño/Niña. Climate Dyn., 43, 1463-1482, https:// doi.org/10.1007/s00382-013-1961-z.

,-- , and T. Yamagata, 2017: Generation and decay mechanisms of Ningaloo Niño/Niña. J. Geophys. Res. Oceans, 122, 8913-8932, https://doi.org/10.1002/2017JC012966.

Kido, S., T. Kataoka, and T. Tozuka, 2016: Ningaloo Niño simulated in the CMIP5 models. Climate Dyn., 47, 1469-1484, https://doi.org/10.1007/s00382-015-2913-6.

Klein, S. A., and D. L. Hartmann, 1993: The seasonal cycle of low stratiform clouds. J. Climate, 6, 1587-1606, https://doi.org/ 10.1175/1520-0442(1993)006<1587:TSCOLS $>2.0$.CO;2.

Lau, N.-C., and M. J. Nath, 2000: Impact of ENSO on the variability of the Asian-Australian monsoons as simulated in GCM experiments. J. Climate, 13, 4287-4309, https://doi.org/ 10.1175/1520-0442(2000)013<4287:IOEOTV>2.0.CO;2.

Li, Y., W. Han, and L. Zhang, 2017: Enhanced decadal warming of the Southeast Indian Ocean during the recent global surface warming slowdown. Geophys. Res. Lett., 44, 9876-9884, https://doi.org/10.1002/2017GL075050.

Madden, R. A., and P. R. Julian, 1971: Detection of a 40-50 day oscillation in the zonal wind in the tropical Pacific. J. Atmos. Sci., 28, 702-708, https://doi.org/10.1175/1520-0469(1971)028<0702: DOADOI $>2.0 . \mathrm{CO} ; 2$.

Marshall, A. G., H. H. Hendon, M. Feng, and A. Schiller, 2015: Initiation and amplification of the Ningaloo Niño. Climate Dyn., 45, 2367-2385, https://doi.org/10.1007/s00382-015-2477-5.

Meyers, G., 1996: Variation of Indonesian throughflow and the El Niño-Southern Oscillation. J. Geophys. Res., 101, 12255 12 263, https://doi.org/10.1029/95JC03729.

Petris, G., S. Petrone, and P. Campagnoli, Eds., 2009: Dynamic linear models. Dynamic Linear Models with $R$, Springer, 31-84, https://doi.org/10.1007/b135794.

Poli, P., and Coauthors, 2016: ERA-20C: An atmospheric reanalysis of the twentieth century. J. Climate, 29, 4083-4097, https://doi.org/10.1175/JCLI-D-15-0556.1.

Rayner, N. A., D. E. Parker, E. B. Horton, C. K. Folland, L. V. Alexander, D. P. Rowell, E. C. Kent, and A. Kaplan, 2003: Global analyses of sea surface temperature, sea ice, and night marine air temperature since the late nineteenth century. J. Geophys. Res., 108, 4407, https://doi.org/10.1029/ 2002JD002670.

Reynolds, R. W., N. A. Rayner, T. M. Smith, D. C. Stokes, and W. Wang, 2002: An improved in situ and satellite SST analysis for climate. J. Climate, 15, 1609-1625, https://doi.org/10.1175/ 1520-0442(2002)015<1609:AIISAS > 2.0.CO;2.

Roeckner, E., and Coauthors, 1996: The atmospheric general circulation model ECHAM-4: Model description and simulation of present-day climate. Max-Planck-Institut für Meteorologie Rep. Series, Tech. Rep. 218, Max-PlanckInstitut für Meteorologie, 94 pp., https://www.mpimet.mpg.de/ fileadmin/publikationen/Reports/MPI-Report_218.pdf.

Saji, N. H., B. N. Goswami, P. N. Vinayachandran, and T. Yamagata, 1999: A dipole mode in the tropical Indian Ocean. Nature, 401, 360-363, https://doi.org/10.1038/43854.

Stenseth, N. C., 2002: Ecological effects of climate fluctuations. Science, 297, 1292-1296, https://doi.org/10.1126/science.1071281.

Tozuka, T., T. Kataoka, and T. Yamagata, 2014: Locally and remotely forced atmospheric circulation anomalies of Ningaloo Niño/Niña. Climate Dyn., 43, 2197-2205, https://doi.org/ 10.1007/s00382-013-2044-x.

Trenary, L. L., and W. Han, 2012: Intraseasonal-to-interannual variability of south Indian Ocean sea level and thermocline: Remote versus local forcing. J. Phys. Oceanogr., 42, 602-627, https://doi.org/10.1175/JPO-D-11-084.1.

Wang, J.-W., W. Han, and R. L. Sriver, 2012: Impact of tropical cyclones on the ocean heat budget in the Bay of Bengal during 1999: 1. Model configuration and evaluation. J. Geophys. Res., 117, C09020, https://doi.org/10.1029/2012JC008372.

Webster, P. J., A. M. Moore, J. P. Loschnigg, and R. R. Leben, 1999: Coupled ocean-atmosphere dynamics in the Indian Ocean during 1997-98. Nature, 401, 356-360, https://doi.org/10.1038/43848.

Zhang, L., 2016: The roles of external forcing and natural variability in global warming hiatuses. Climate Dyn., 47, 31573169, https://doi.org/10.1007/s00382-016-3018-6.

- and T. Li, 2017: Relative roles of differential SST warming, uniform SST warming and land surface warming in determining the Walker circulation changes under global warming. Climate Dyn., 48, 987-997, https://doi.org/10.1007/s00382-016-3123-6. , and K. B. Karnauskas, 2017: The role of tropical interbasin SST gradients in forcing Walker circulation trends. J. Climate, 30, 499-508, https://doi.org/10.1175/JCLI-D-16-0349.1.

— , and W. Han, 2018: Impact of Ningaloo Niño on tropical Pacific and an inter-basin coupling mechanism. Geophys. Res. Lett., https://doi.org/10.1029/2018GL078579, in press.

,-- , and F. Sienz, 2018: Unraveling causes for the changing behavior of tropical Indian Ocean in the past few decades. J. Climate, 31, 2377-2388, https://doi.org/10.1175/ JCLI-D-17-0445.1.

Zhang, N., M. Feng, H. H. Hendon, A. J. Hobday, and J. Zinke, 2017: Opposite polarities of ENSO drive distinct patterns of coral bleaching potentials in the southeast Indian Ocean. Sci. Rep., 7, 2443, https://doi.org/10.1038/s41598-017-02688-y.

Zinke, J., A. Rountrey, M. Feng, S. P. Xie, D. Dissard, K. Rankenburg, J. M. Lough, and M. T. McCulloch, 2014: Corals record long-term Leeuwin current variability including Ningaloo Niño/Niña since 1795. Nat. Commun., 5, L16302, https://doi.org/10.1038/ncomms4607. 